Prepared in cooperation with the Federal Emergency Management Agency

\title{
Flood of April 2007 in Southern Maine
}

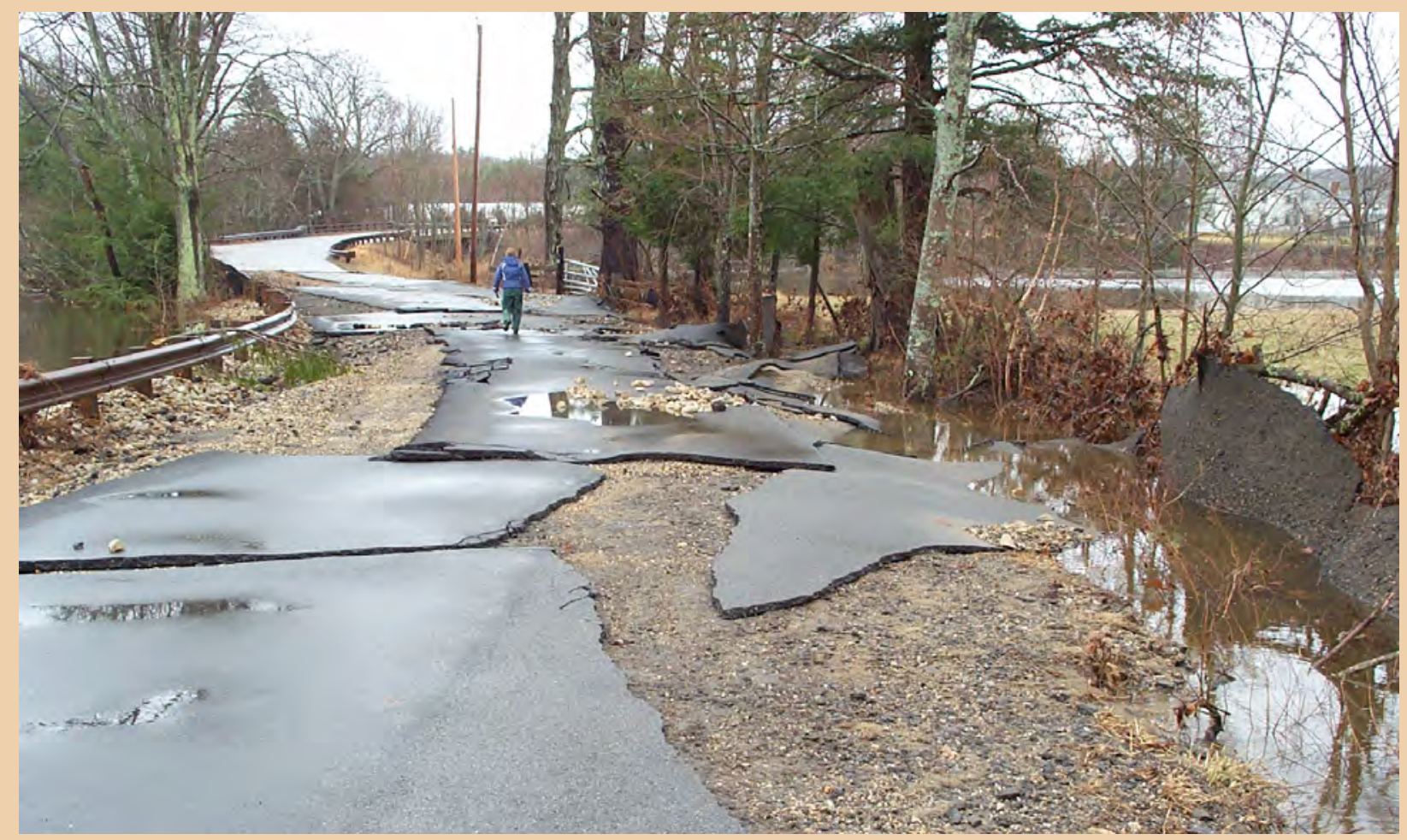

Scientific Investigations Report 2009-5102 
Cover. Photograph of Great Works River at Emery Bridge Road washout, South Berwick, Maine, April 2007. 


\section{Flood of April 2007 in Southern Maine}

By Pamela J. Lombard

Prepared in cooperation with the Federal Emergency Management Agency

Scientific Investigations Report 2009-5102 


\section{U.S. Department of the Interior \\ KEN SALAZAR, Secretary \\ U.S. Geological Survey \\ Suzette M. Kimball, Acting Director}

U.S. Geological Survey, Reston, Virginia: 2009

For more information on the USGS - the Federal source for science about the Earth, its natural and living resources, natural hazards, and the environment, visit http://www.usgs.gov or call 1-888-ASK-USGS

For an overview of USGS information products, including maps, imagery, and publications, visit http://www.usgs.gov/pubprod

To order this and other USGS information products, visit http://store.usgs.gov

Any use of trade, product, or firm names is for descriptive purposes only and does not imply endorsement by the U.S. Government.

Although this report is in the public domain, permission must be secured from the individual copyright owners to reproduce any copyrighted materials contained within this report.

Suggested citation:

Lombard, P.J., 2009, Flood of April 2007 in southern Maine: U.S. Geological Survey Scientific Investigations Report 2009-5102, 34 p., available only online at http://pubs.usgs.gov/sir/2009/5102. 


\section{Contents}

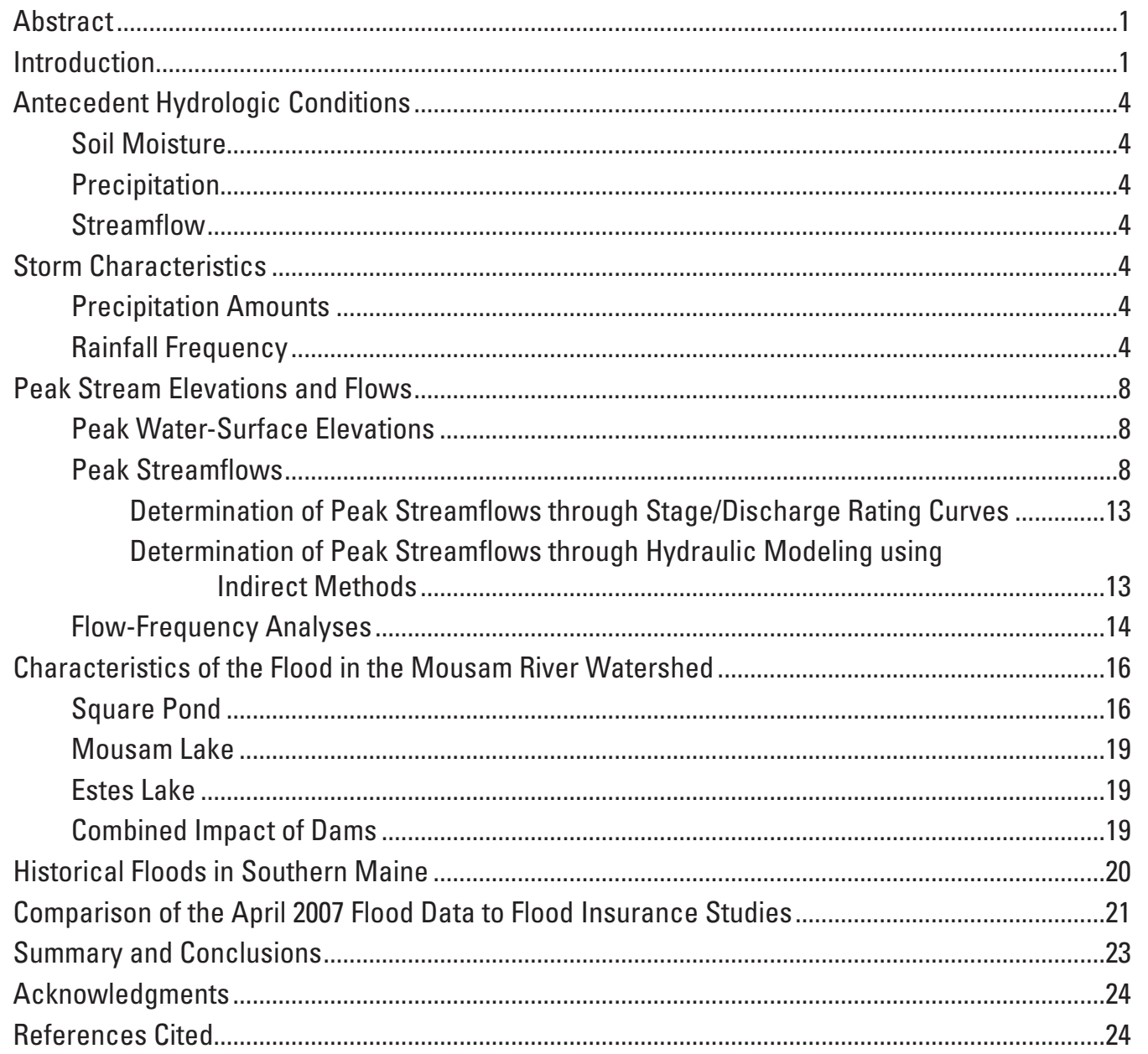




\section{Figures}

1. Photograph showing Keay Brook washout of Ridlon Road, April 2007, Berwick, Maine.....

2. Map showing location of study area and data-collection sites, southern Maine.............3

3. Map showing total precipitation for 3-day period from April 15 through 18, 2007, southern Maine and New Hampshire (from Jensenius and others, 2007)..... .5

4. Map showing 24-hour rainfall in southern Maine and New Hampshire from 7:00 a.m. April 15 through 7:00 a.m. April 16, 2007.

5. Map showing change in water content in snowpack from April 10 through 19, 2007, southern Maine

6. Photograph showing marker indicating high-water elevation, April $2007 \mathrm{flood}$, southern Maine

7. Photograph showing marker at debris line on bark of tree indicating high-water elevation, April 2007 flood, southern Maine....

8. Photograph showing debris line indicating high-water elevation along Little River near Longswamp Road, April 2007 flood, Berwick, Maine

9. Map showing location of sites where high-water marks were surveyed following the April 2007 flood in southern Maine.....

10. Photograph showing streamflow measurement taken with acoustic Doppler current profiler on Nezinscot River, April 17, 2007, Turner, Maine

11. Map showing peak streamflow recurrence intervals for selected sites, April 2007

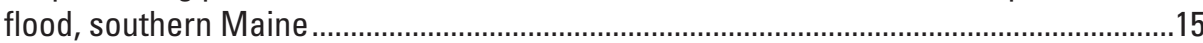

12. Map showing location of dams and U.S. Geological Survey streamflow-gaging stations in the Mousam River watershed, southern Maine

\section{Tables}

1. Peak water-surface elevations for April 2007 flood in York and Cumberland Counties, Maine.

2. Peak flows for selected recurrence intervals and peak flows calculated for the April 2007 flood in southern Maine.

3. Mousam River watershed drainage areas, streamflows, and reservoir storage, southern Maine

4. April 2007 peak flows in comparison to May 2006 peak flows in southern Maine ..........20

5. Relation of computed April 2007 flood discharges and high-water mark elevations to flood-insurance study data for selected locations in southern Maine. 


\section{Conversion Factors and Datum}

Inch/Pound to SI

\begin{tabular}{lcl}
\hline \multicolumn{1}{c}{ Multiply } & \multicolumn{1}{c}{ By } & \multicolumn{1}{c}{ To obtain } \\
\hline inch (in.) & Length & \\
foot $(\mathrm{ft})$ & 25.4 & millimeter $(\mathrm{mm})$ \\
mile (mi) & 0.3048 & meter \\
\hline & 1.609 & kilometer \\
\hline square mile $\left(\mathrm{mi}^{2}\right)$ & Area & \\
\hline & 2.590 & square kilometer \\
\hline cubic foot $\left(\mathrm{ft}^{3}\right)$ & Volume & \\
\hline & 0.02832 & cubic meter \\
\hline cubic foot per second $\left(\mathrm{ft}^{3} / \mathrm{s}\right)$ & Flow rate & \\
\hline
\end{tabular}

Temperature in degrees Fahrenheit $\left({ }^{\circ} \mathrm{F}\right)$ may be converted to degrees Celsius $\left({ }^{\circ} \mathrm{C}\right)$ as follows:

$$
{ }^{\circ} \mathrm{C}=\left({ }^{\circ} \mathrm{F}-32\right) / 1.8
$$

Vertical coordinate information is referenced to the North American Vertical Datum of 1988 (NAVD 88).

Horizontal coordinate information is referenced to the North American Datum of 1983 (NAD 83). Altitude, as used in this report, refers to distance above the vertical datum. 


\title{
Flood of April 2007 in Southern Maine
}

\author{
By Pamela J. Lombard
}

\section{Abstract}

Up to 8.5 inches of rain fell from April 15 through 18, 2007, in southern Maine. The rain - in combination with up to an inch of water from snowmelt - resulted in extensive flooding. York County, Maine, was declared a presidential disaster area following the event.

The U.S. Geological Survey, in cooperation with the Federal Emergency Management Agency (FEMA), determined peak streamflows and recurrence intervals at 24 locations and peak water-surface elevations at 63 sites following the April 2007 flood. Peak streamflows were determined with data from continuous-record streamflow-gaging stations where available and through hydraulic models where station data were not available. The flood resulted in peak streamflows with recurrence intervals greater than 100 years throughout most of York County, and recurrence intervals up to 50 years in Cumberland County. Peak flows for selected recurrence intervals varied from less than 10 percent to greater than 100 percent different than those in the current FEMA floodinsurance studies due to additional data or newer regression equations. Water-surface elevations observed during the April 2007 flood were bracketed by elevation profiles in FEMA flood-insurance studies with the same recurrence intervals as the recurrence intervals bracketing the observed peak streamflows at seven sites, with higher elevation-profile recurrence intervals than streamflow recurrence intervals at six sites, and with lower elevation-profile recurrence intervals than streamflow recurrence intervals at one site.

The April 2007 flood resulted in higher peak flows and water-surface elevations than the flood of May 2006 in coastal locations in York County, and lower peak flows and watersurface elevations than the May 2006 flood further from the coast and in Cumberland County. The Mousam River watershed with over 13 dams and reservoirs was severely impacted by both events. Analyses indicate that the April 2007 peak streamflows in the Mousam River watershed occurred despite the fact that up to 287 million $\mathrm{ft}^{3}$ of runoff was stored by 13 dams and reservoirs.

\section{Introduction}

The April 2007 storm, which is commonly referred to in Maine as the Patriots' Day Storm, produced strong winds, tornadoes, high waves, beach erosion, and riverine and coastal flooding in communities from South Carolina to Maine from April 15 through 18, 2007. The storm, resulting from a major low-pressure system, reached peak intensity on April 16 off the coast of New Jersey but still produced up to 8.5 in. of rain in southern Maine (National Weather Service, written commun., 2007). The storm produced hurricane-force winds and extreme rainfall in Maine, causing storm surges and flooding in coastal areas and extensive flooding of streams and rivers inland. The State of Maine declared a state of emergency as a result of the flooding caused by the Patriots' Day Storm. Federal disaster areas were declared in Androscoggin, Cumberland, Franklin, Hancock, Kennebec, Knox, Lincoln, Oxford, Sagadahoc, Somerset, Waldo, Washington, and York Counties. The Maine Emergency Management Agency (MEMA) estimated damages to public infrastructure associated with the Patriots' Day Storm at \$45 million, including $\$ 31.5$ million to roads alone (fig. 1). Damage to private homes and property also was extensive. Over $\$ 16.2$ million was spent by the Federal Emergency Management Agency (FEMA) on 1,600 damage-repair projects in the 13 counties associated with the April 2007 flood (Federal Emergency Management Agency, written commun., 2007).

The documentation of peak flood-water heights and peak-streamflow magnitudes and frequencies associated with extreme events provides water-resource managers and emergency-management workers with essential data for the delineation of floodplains necessary for accurate land-use planning and for flood-mitigation decisions. Peak-flood data are important for the calibration of models used to establish and assess 100-year and 500-year floodplain limits and profiles.

The magnitude and frequency of flooding are critical engineering information used by the Maine Department of Transportation and local public-works officials to accurately size new bridges and culverts. An oversized bridge will cost additional money to build, and an undersized bridge will increase the risk of the structure getting damaged or destroyed during its design life. Flood analyses guide improvements to emergency-action plans for affected communities. Flood documentation in a disaster area is crucial for the development of mitigation measures to prevent future flood losses and for appropriate allocation of disaster-assistance funding when the next extreme event occurs.

The U.S. Geological Survey (USGS), in cooperation with FEMA, began a study in 2007 to document the antecedent conditions, precipitation, and streamflows associated with the severe riverine flooding in Maine in April 2007 caused 


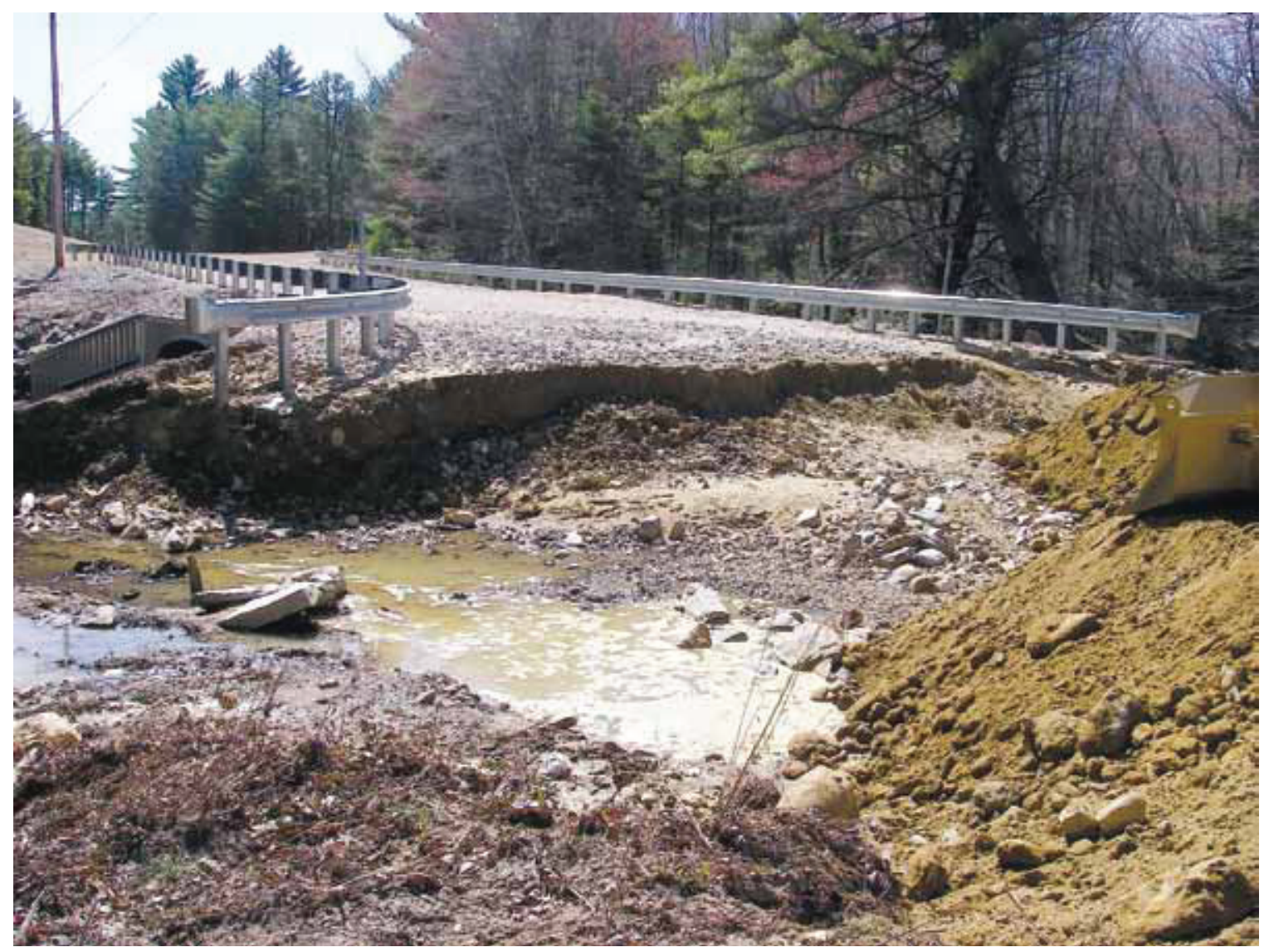

Figure 1. Keay Brook washout of Ridlon Road, April 2007, Berwick, Maine.

by the Patriots' Day Storm. Initially, the USGS identified, flagged, and surveyed high-water marks (HWMs) in southern Maine and provided FEMA with locations and elevations for the HWMs in June 2007. As a part of this preliminary work, the USGS computed peak flows and recurrence intervals for the Mousam River near West Kennebunk and for the Little Ossipee River near South Limington associated with the April 15 through 18, 2007 extreme flooding in these areas. Recurrence intervals between 100 and 500 years were documented at the above locations on the Mousam and Little Ossipee Rivers for the April 2007 flood (Hodgkins and others, 2007).

The April 2007 flood affected many of the same locations and rivers as the May 2006 flood in York County. Peak streamflows and recurrence intervals for 9 streams and peak water-surface elevations at 25 sites were published for the May 2006 flood (Stewart and Kempf, 2008). One stage/ discharge rating extension and six calibrated hydraulic models developed after the May 2006 flood were also used to compute peak discharges for the April 2007 flood. In addition, 11 new hydraulic models and 5 new rating extensions were developed specifically for this study.

Severe flooding occurred in the Mousam River watershed (fig. 2) during both the May 2006 and April 2007 floods. This watershed is characterized by numerous small dams and reservoirs, and has the potential to be highly regulated. It was unclear to water-resource managers how much of an impact the dams could have on events equivalent to or greater than the 100-year event. This study includes estimates of how the storage capacities, inflows, and outflows of the many reservoirs might have interacted cumulatively to affect flooding in the Mousam River watershed during the April 2007 flood. Reservoir volumes and surface areas and dam dimensions were obtained from the Maine Department of Environmental Protection (MaineDEP) Emergency Action Plans and include many assumptions. 


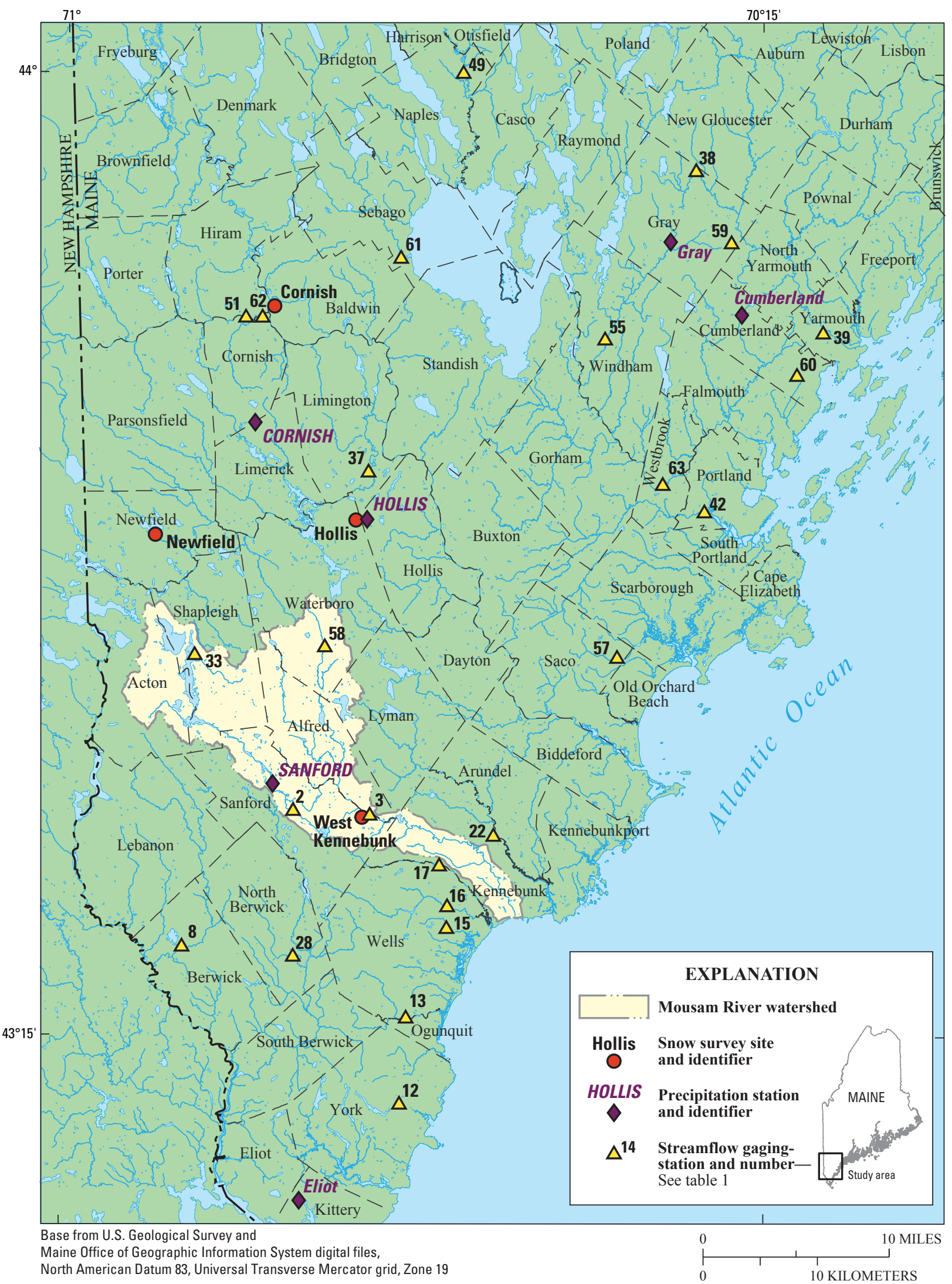

Figure 2. Location of study area and data-collection sites, southern Maine. 


\section{Antecedent Hydrologic Conditions}

Hydrologic conditions in the weeks and months prior to a flood can have a substantial impact on peak streamflows and peak elevations resulting from the flood. Antecedent hydrologic conditions that can affect the severity of a flood include stream stage and discharge, percent soil saturation and (or) degree of frozen soils, and ground-water levels. Relatively little hydrologic information that describes hydraulic conditions prior to the April 2007 flood in southern Maine is available; however, soil moisture, precipitation, and streamflow records that are available are summarized below.

\section{Soil Moisture}

Soil moisture was from 0 to $40 \mathrm{~mm}$ above average in southern Maine from December 2006 through February 2007 (accessed from the National Oceanic and Atmospheric Administration National Weather Service at http://www.nws. noaa.gov/ost/climate/STIP/nasm_fcst $07 . h$ tm on May 5, 2009). In March 2007, soil moisture was average in York and Cumberland Counties, Maine. In April 2007, most of Maine had soil moisture that was $20 \mathrm{~mm}$ above normal, but this period includes the precipitation from the Patriots' Day Storm.

\section{Precipitation}

Portland, Maine, received 14.3 and 14.1 in. of snowfall in February and March 2007, respectively, which was 1.5 and $1.1 \mathrm{in}$. above normal for those months based on 126 years of record (National Oceanic and Atmospheric Administration, 2002). On April 9, 2007, a thin, wet snowpack covered the ground in the Mousam and Little Ossipee River Basins. Snowpack was measured at four locations in or near the basins on April 9, 2007, as part of the Maine Cooperative Snow Survey program-West Kennebunk, Newfield, Hollis, and Cornish (fig. 2). Snowpack depths ranged from 2.4 to 5.3 in. and had an equivalent water content of 0.8 to $1.5 \mathrm{in}$.

Portland, Maine, received 3.01 in. of rain in March 2007, which was $1.13 \mathrm{in}$. below normal (National Oceanic and Atmospheric Administration, 2002) based on 137 years of precipitation record at this site. Gray, Maine, received 3.94 in. of rain during March 2007 (National Weather Service, 2008).

\section{Streamflow}

The largest streamflows in Maine typically occur in the spring (March, April, and May) when rain falls on a dense (ripe) snowpack or on saturated soils. Streamflows recede as snowmelt ends and evapotranspiration increases. In the spring of 2007, there were no active continuous-record streamflowgaging stations in York County, Maine. March 2007 mean streamflow on the Saco River at Cornish in Cumberland County, Maine (site 62 , fig. 2), was $2,490 \mathrm{ft}^{3} / \mathrm{s}$, which is in the normal range for March. March 2007 mean streamflow on Stony Brook at East Sebago, Maine (also in Cumberland County) (site 61, fig. 2), was $2.37 \mathrm{ft}^{3} / \mathrm{s}$. Although this is in the normal range for March, there are only 12 years of record at this site. On the basis of the limited data available, antecedent streamflow conditions were in the normal range in March 2007 in southern Maine.

\section{Storm Characteristics}

\section{Precipitation Amounts}

Large amounts of rainfall fell in southern Maine from April 15 through 18, 2007. Rainfall totals for the 3-day storm were $8.42,8.56,7.08$, and 6.83 in. at precipitation stations in Eliot, Sanford, Hollis, and Cornish, respectively (Jensenius and others, 2007) (figs. 2 and 3). Twenty-four hour precipitation totals from 7:00 a.m. Sunday, April 15, through 7:00 a.m. Monday, April 16, at these same locations were 6.93, 5.92, 4.02, and 3.2 in., respectively (fig. 4). Maximum 24-hour precipitation during the Patriots' Day Storm occurred from the afternoon of April 15 through the afternoon of April 16, 2007, and was calculated to be $7.58,4.97$, and 4.60 in. at continuously recording precipitation stations in Sanford, Hollis, and Cornish, respectively (T. Hawley, National Weather Service, written commun., 2007; Hodgkins and others, 2007).

Snowpack was measured at West Kennebunk, Newfield, Hollis, and Cornish in York and Cumberland Counties on April 19, 2007 (snowpack was measured at the same locations on April 9) (see section Antecedent Hydrologic Conditions) above. There was either no snow or trace amounts of snow at these sites on April 19 (Maine Cooperative Snow Survey, 2007). The reduction in snowpack water content from April 9 to 19 averaged $1 \mathrm{in}$. throughout most of York and Cumberland Counties. Extreme northern parts of this region had no substantial change in snowpack water content (fig. 5). A storm on April 12 and 13 may have changed the equivalent water content in the snowpack prior to the April 2007 flood (T. Hawley, National Weather Service, written commun., 2007). The reduction in snowpack water content that took place during the April 2007 flood augmented runoff from storm precipitation totals in streams.

\section{Rainfall Frequency}

The Atlas of Precipitation Extremes for the Northeastern United States and Southeastern Canada contains maps with recurrence-interval isolines for 1-, 2-, 4-, 7-, and 10-day rainfall totals (Wilks and Cember, 1993). The T-year (where T equals $100,50,25,10,5$, and 2) rainfall recurrence intervals for southern Maine were interpolated from these maps. The recurrence interval is the average period of time between rainfalls that are greater than or equal to a specified magnitude. The 100-year rainfall is the rainfall that would be equaled or 


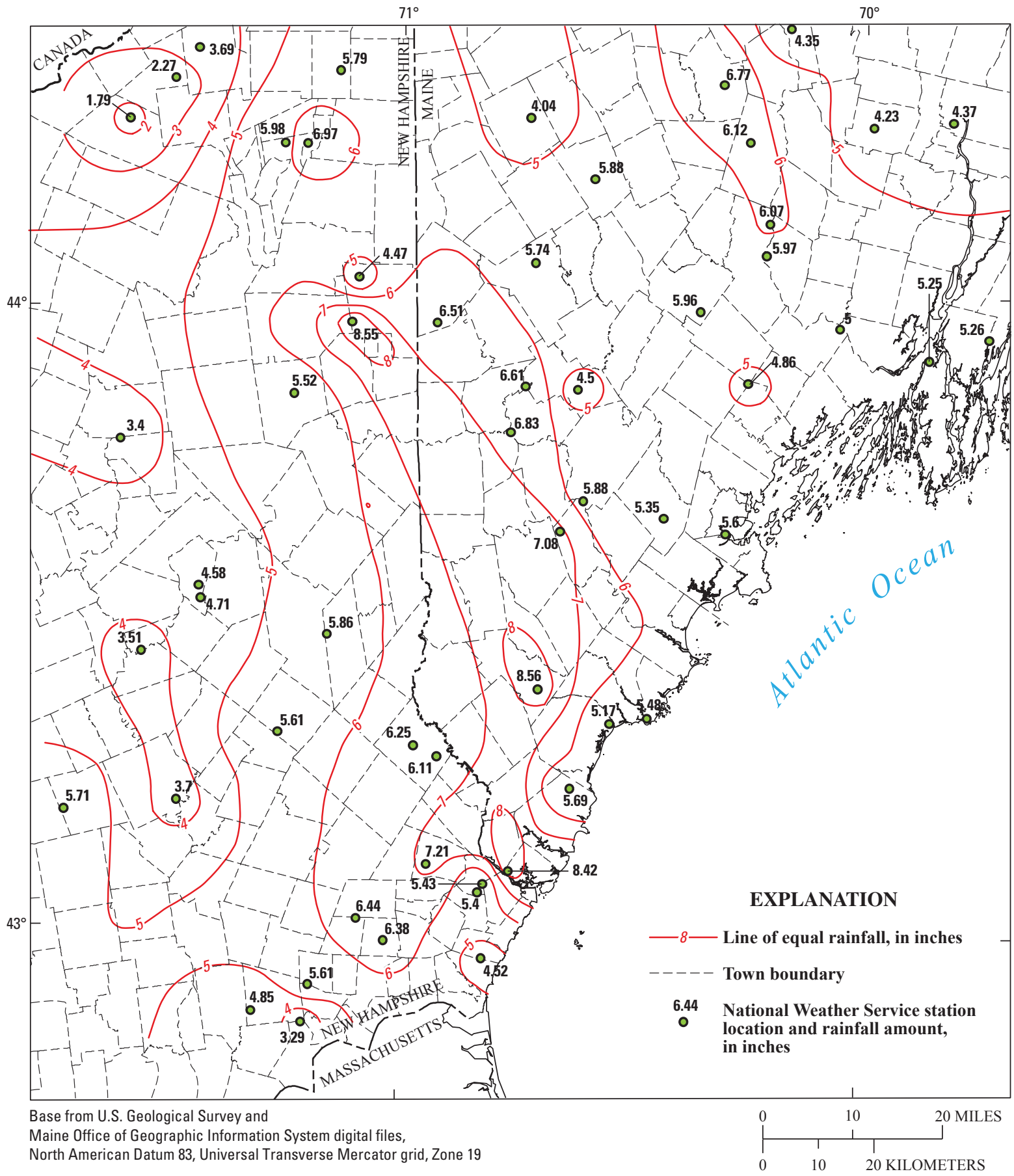

Figure 3. Total precipitation for 3-day period from April 15 through 18, 2007, southern Maine and New Hampshire (from Jensenius and others, 2007). 


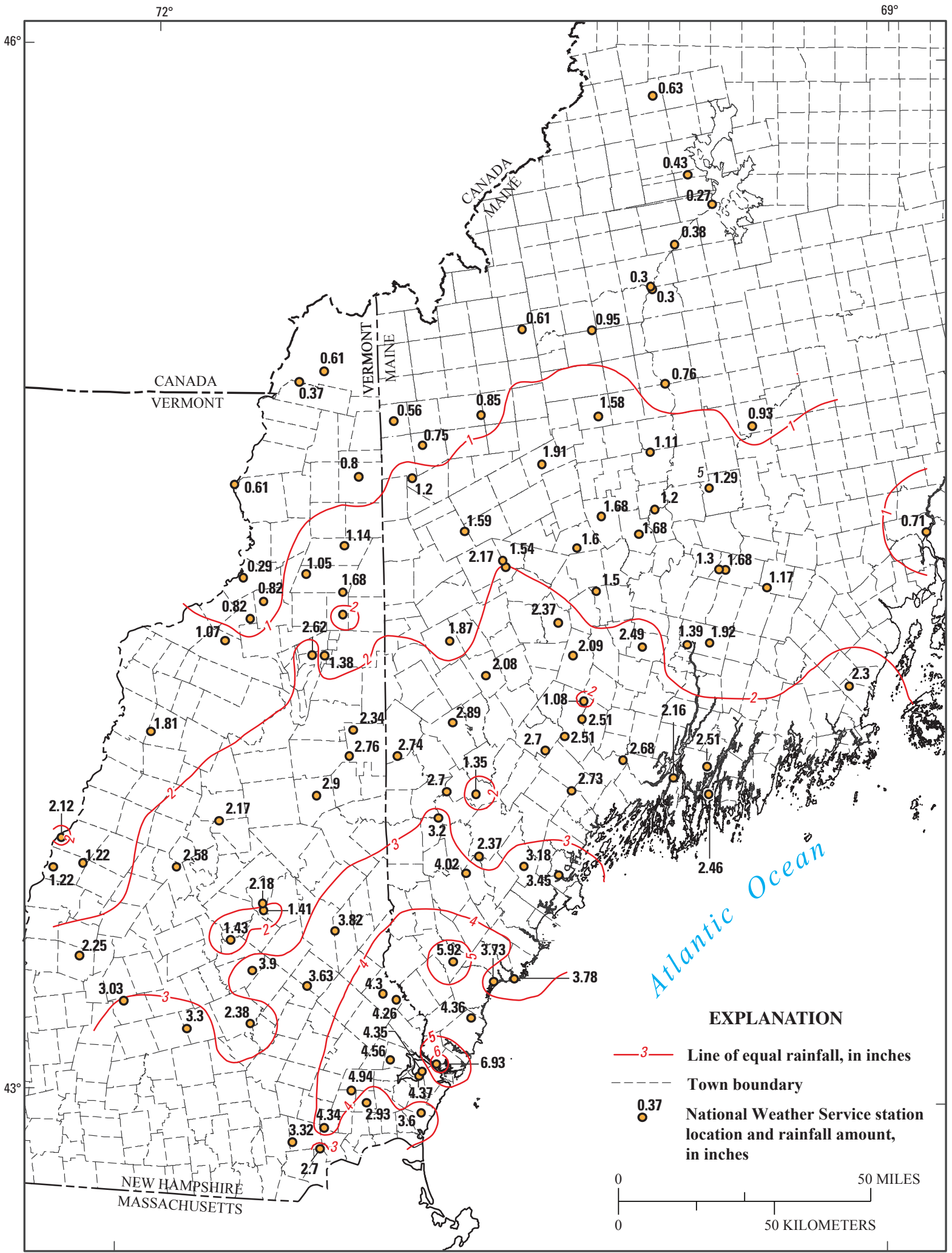

Base from U.S. Geological Survey and

Maine Office of Geographic Information System digital files,

North American Datum 83, Universal Transverse Mercator grid, Zone 19

Figure 4. Twenty-four-hour rainfall in southern Maine and New Hampshire from 7:00 a.m. April 15 through 7:00 a.m. April 16, 2007. 


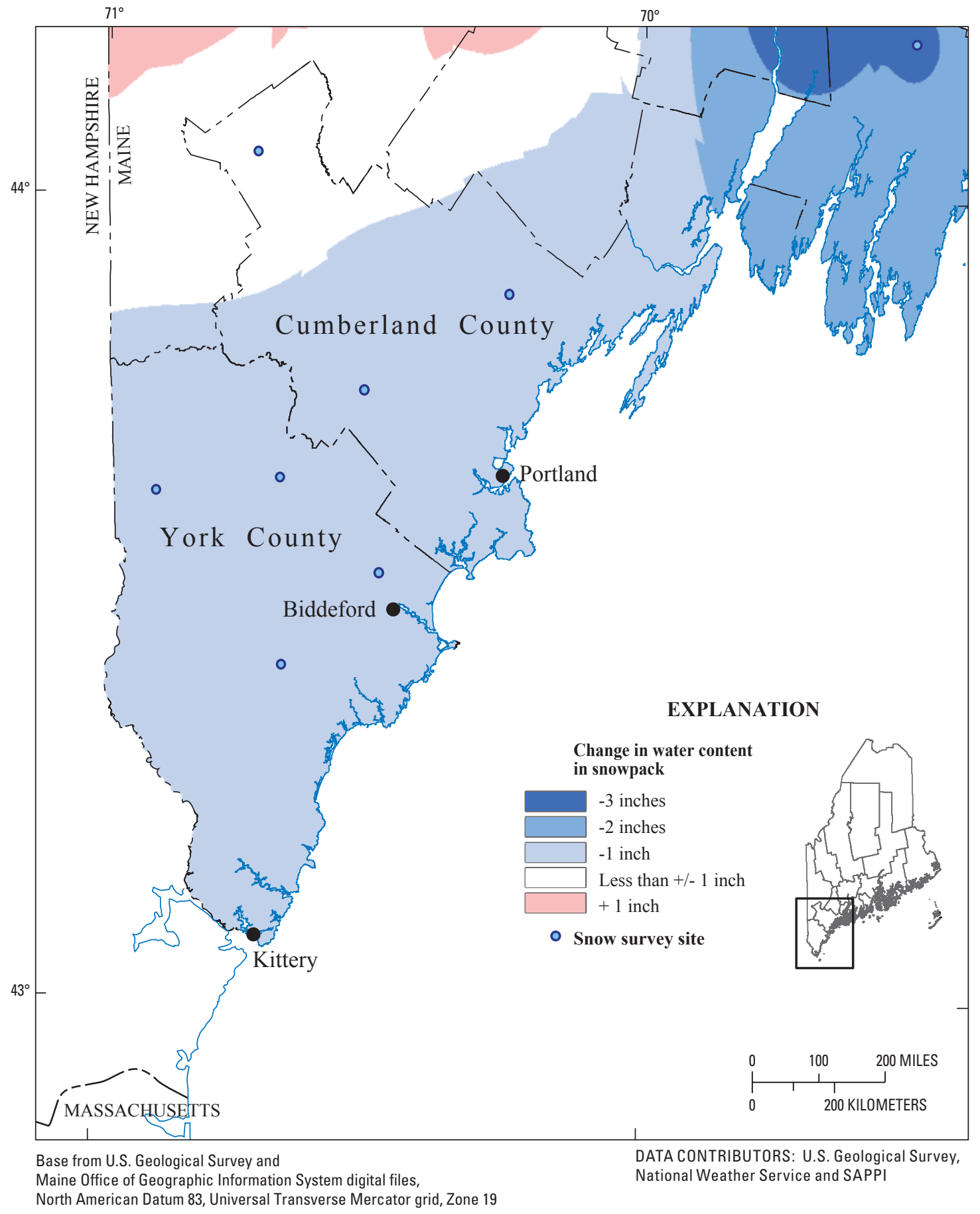

Figure 5. Change in water content in snowpack from April 10 through 19, 2007, southern Maine. 
exceeded on average once every 100 years. This means there is a 1.0 percent chance that a rainfall of this magnitude will be equaled or exceeded in any given year. The 100-year rainfall totals for 2-, 4-, 7-, and 10-day periods in southern Maine are 8, 9, 11, and 12 in., respectively (Wilks and Cember, 1993). The average rainfall, based on the National Weather Service precipitation records during the Patriots' Day Storm in April of 2007 was roughly equivalent to the 100 -year recurrence interval for 2-day rainfall totals near Sanford, Maine (fig. 2).

\section{Peak Stream Elevations and Flows}

The rain that fell in York and Cumberland Counties between April 15 and 18, 2007, in addition to up to an inch of equivalent water from snowmelt, resulted in extreme water-surface elevations and streamflows in rivers in parts of southern Maine. Peak water-surface elevations and the magnitude and recurrence interval of peak streamflows are described below.

\section{Peak Water-Surface Elevations}

Peak water-surface elevations are based on recorded stage at continuously recording streamflow-gaging stations or crest-stage gaging stations where available and on HWMs identified using the techniques of Benson and Dalrymple (1967) where station data are not available. No continuousrecord streamflow-gaging stations on unregulated streams were in operation in April 2007 in the regions of York and Cumberland Counties most heavily impacted by the flood. The Presumpscot River at Westbrook, Maine (USGS station number 01064118 , site number 63 , fig. 2), crested at $38.0 \mathrm{ft}$ NAVD 88 at 7:45 p.m. on April 16, 2007, $10 \mathrm{ft}$ above the National Weather Service flood stage of $27.7 \mathrm{ft}$ NAVD 88. The Presumpscot River is regulated at the outlet of Sebago Lake. The Saco River at Cornish (USGS station number 01066000, site number 62, fig. 2) and Stony Brook at East Sebago (USGS station number 01063310, site number 61, fig. 2) are on the outskirts of the region affected by the April 2007 flood. Stony Brook at East Sebago crested at $282.5 \mathrm{ft}$ NAVD 88 at 1:00 p.m. on April 16, 2007, and the Saco River at Cornish crested at $274.1 \mathrm{ft} \mathrm{NAVD} 88$ at $11: 15$ p.m. on April 16, 2007 (table 1 in back of report). The Saco River at Cornish is regulated by several upstream power plants. Peak water-surface elevations were measured at Chenery Brook near Cumberland (USGS station number 01060070, site number 60, fig. 2) and unnamed brook at Gray (USGS station number 01059845 , site number 59, fig. 2) with crest-stage gaging stations in operation during the April 2007 flood (table 1 in back of report).

HWMs such as debris lines or wash lines caused by the flooding event can be located, marked, and rated in the days following a storm (fig. 6). Debris lines usually consist of fine material such as silt, hemlock needles, or seeds deposited by peak water surfaces on trees (fig. 7), bridge abutments, buildings, or streambanks (fig. 8). Wash lines are defined by the removal or washing away of soil, debris, and leaves by flood peaks. It is essential to mark all HWMs as soon as possible after the event because they can quickly fade or wash away in subsequent storms. HWMs are rated on the basis of the type and quality of the debris line or wash line as well as other corroborating evidence in the area. The accuracy of the mark is defined as follows: a high-water mark having an excellent rating is estimated to be within $0.05 \mathrm{ft}$ of the actual peak water surface; a good mark is within $0.1 \mathrm{ft}$; a fair mark is within $0.2 \mathrm{ft}$; and a poor mark may be greater than $0.2 \mathrm{ft}$ from the true peak water surface during the event.

Peak water-surface elevations were determined for 160 points at 62 sites on 33 rivers and streams in York and Cumberland Counties, Maine, following the April 2007 flood (table 1 in back of report, fig. 9). Most of the documented HWMs were upstream or downstream of bridges, culverts, and dams or at discontinued streamflow-gaging stations or creststage gaging stations. The locations of sites where HWMs were identified (one to four marks per site) are shown on figure 9, and the elevations of the HWMs are listed in table 1 (in back of report). All HWMs included in this report were referenced to NAVD 88 using High Precision Global Positioning System (GPS) instrumentation. At sites where a continuous-record streamflow-gaging station was in operation, peak water-surface elevations were recorded by the station and the identification of HWMs was unnecessary. The time of the peak elevation or the peak flow from the April 2007 flood is not known for any of the points listed in table 1 (in back of report) except at the continuously recording streamflowgaging stations (sites 61-63).

\section{Peak Streamflows}

Peak streamflows associated with the April 2007 flood were calculated at 24 sites in York and Cumberland Counties, Maine (table 2). Methods used to determine peak streamflows include the development of a relation between streamflow and water-surface elevation (a rating curve) at a continuous-record station or crest-stage station, which is periodically updated with streamflow measurements at or near the peak flow (fig. 10), and the development of hydraulic models and indirect methods at sites where a rating curve was not available or was unreliable for extremely high flows. Indirect methods are based on hydraulic modeling in which peak flows are estimated as those flows which produce modeled water-surface elevations that match HWMs observed in the field. Indirect methods of determining peak flow are based on hydraulic relations between flow and the geometry of the channel or hydraulic structures such as bridges or culverts (Benson and Dalrymple, 1967; Matthai, 1967). Peak streamflows were determined with rating curves at eight sites and hydraulic models and indirect methods at 16 sites in York and Cumberland Counties following the April 2007 flood. 


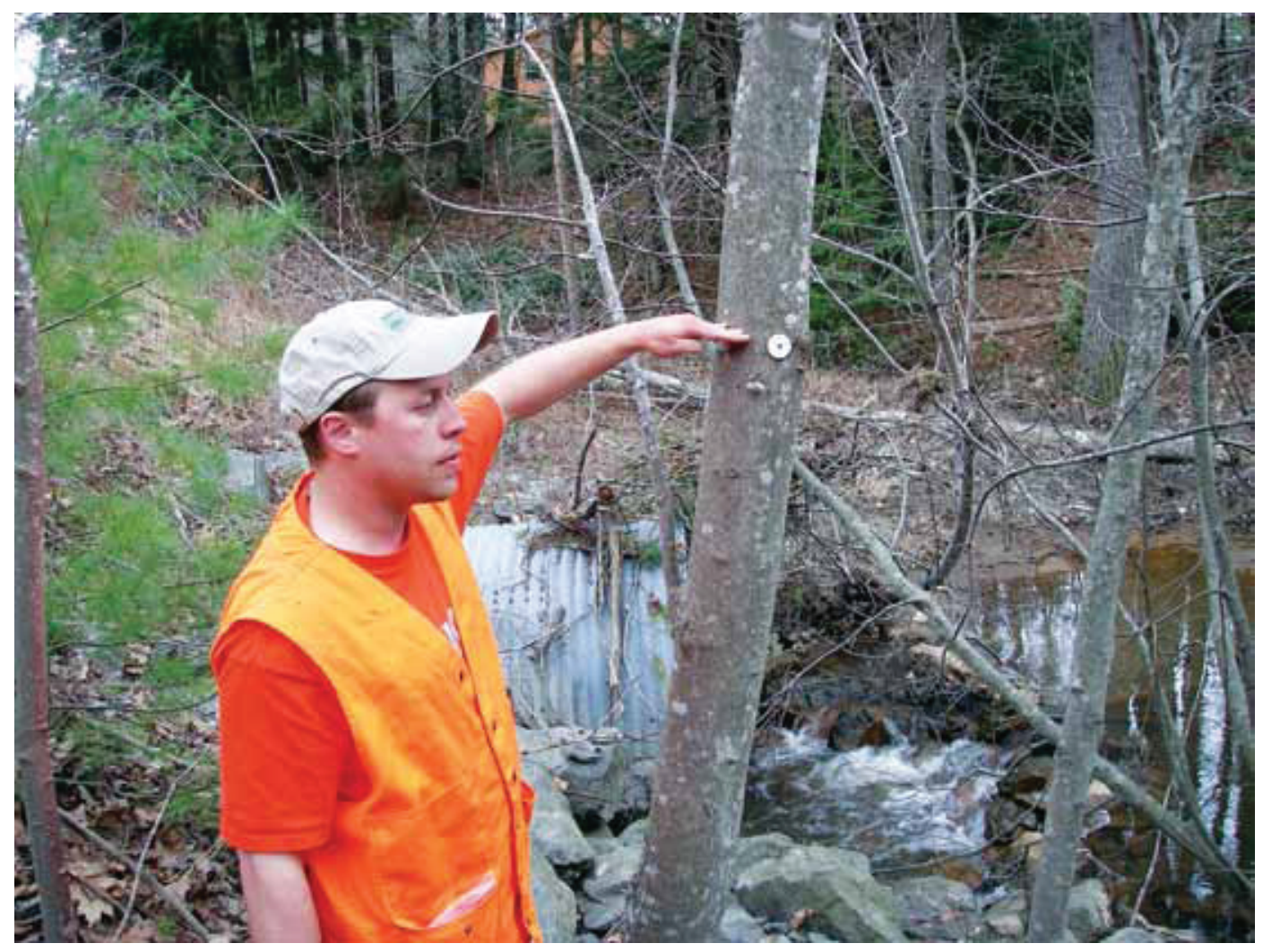

Figure 6. Marker indicating high-water elevation, April 2007 flood, southern Maine.

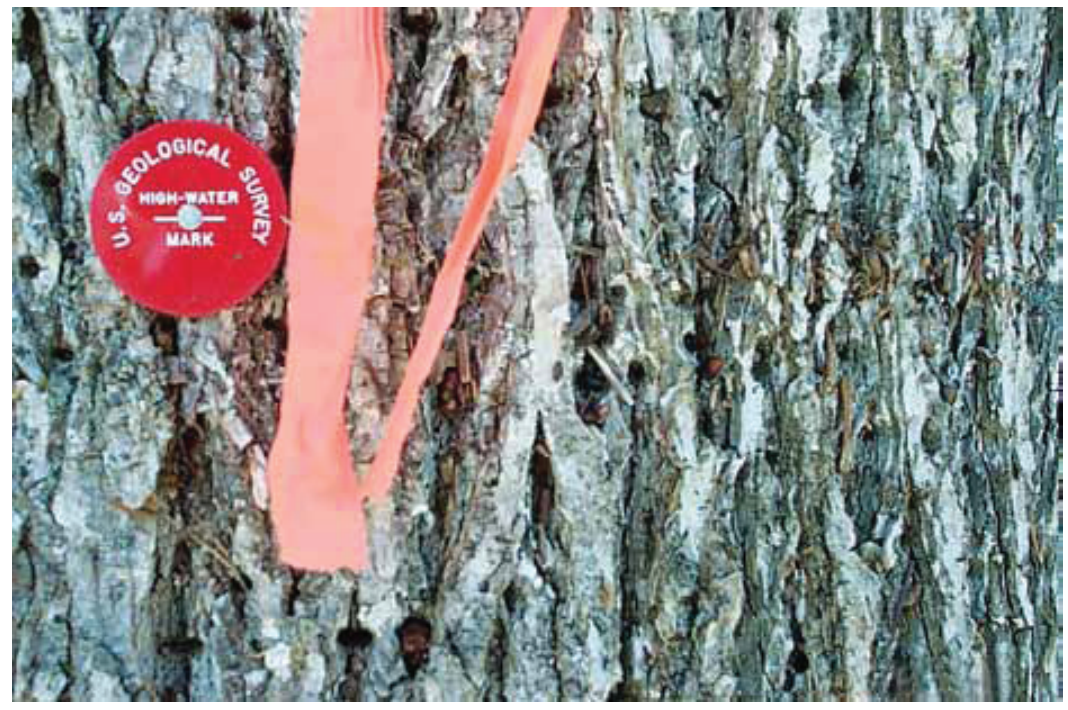

Figure 7. Marker at debris line on bark of tree indicating high-water elevation, April 2007 flood, southern Maine. 


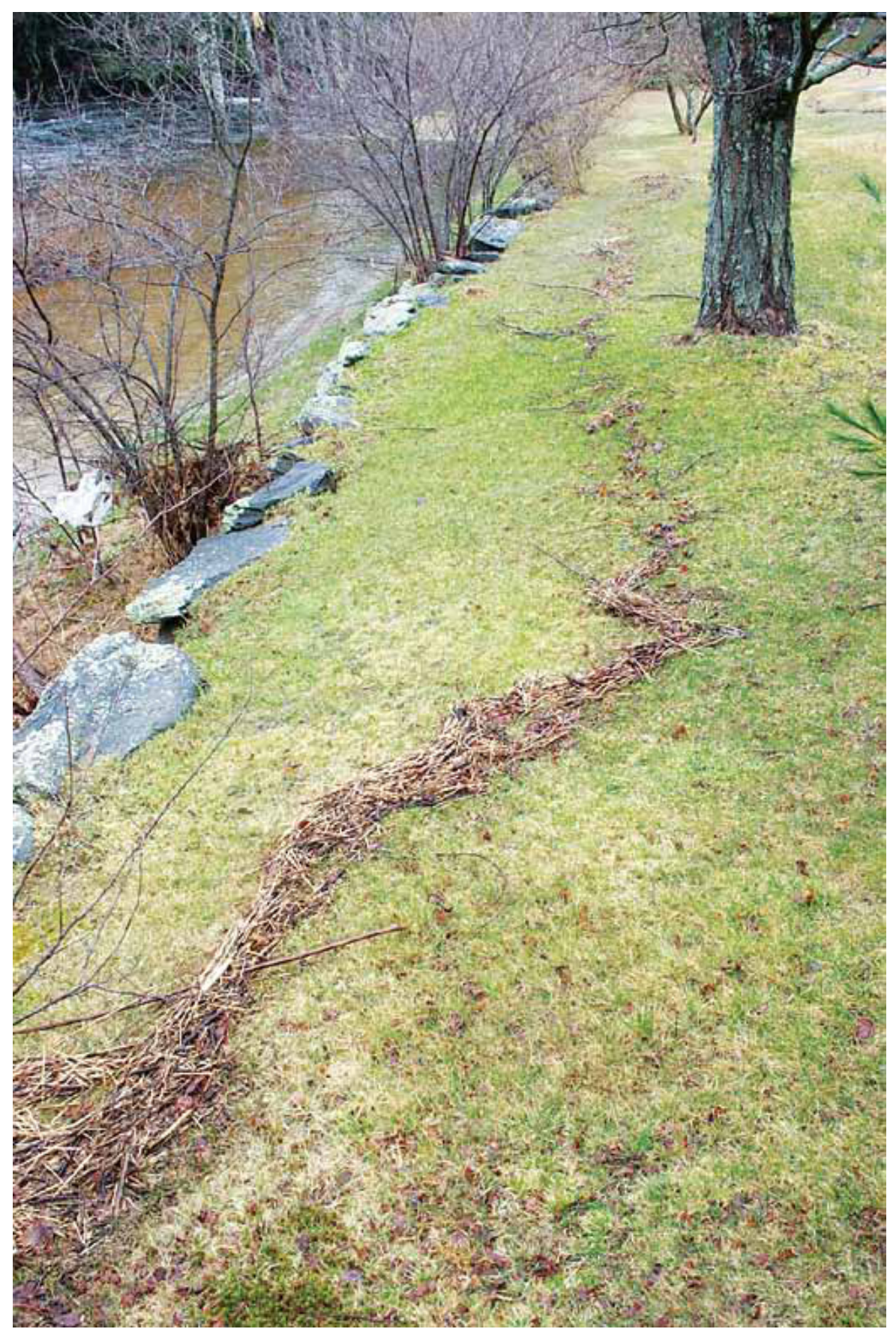

Figure 8. Debris line indicating highwater elevation along Little River near Longswamp Road, April 2007 flood, Berwick, Maine. 


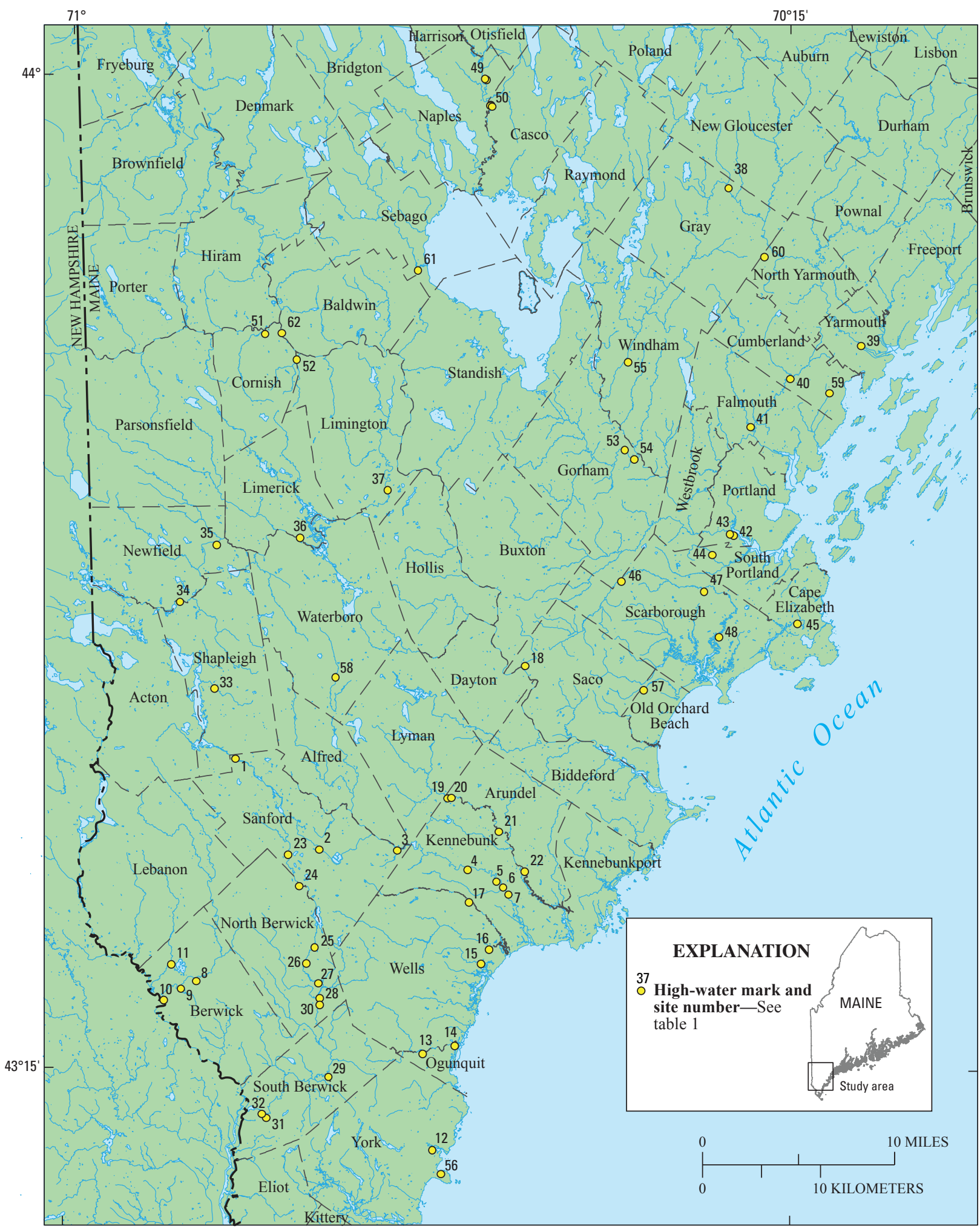

Base from U.S. Geological Survey and

Maine Office of Geographic Information System digital files,

North American Datum 83, Universal Transverse Mercator grid, Zone 19

Figure 9. Location of sites where high-water marks were surveyed following the April 2007 flood in southern Maine. 


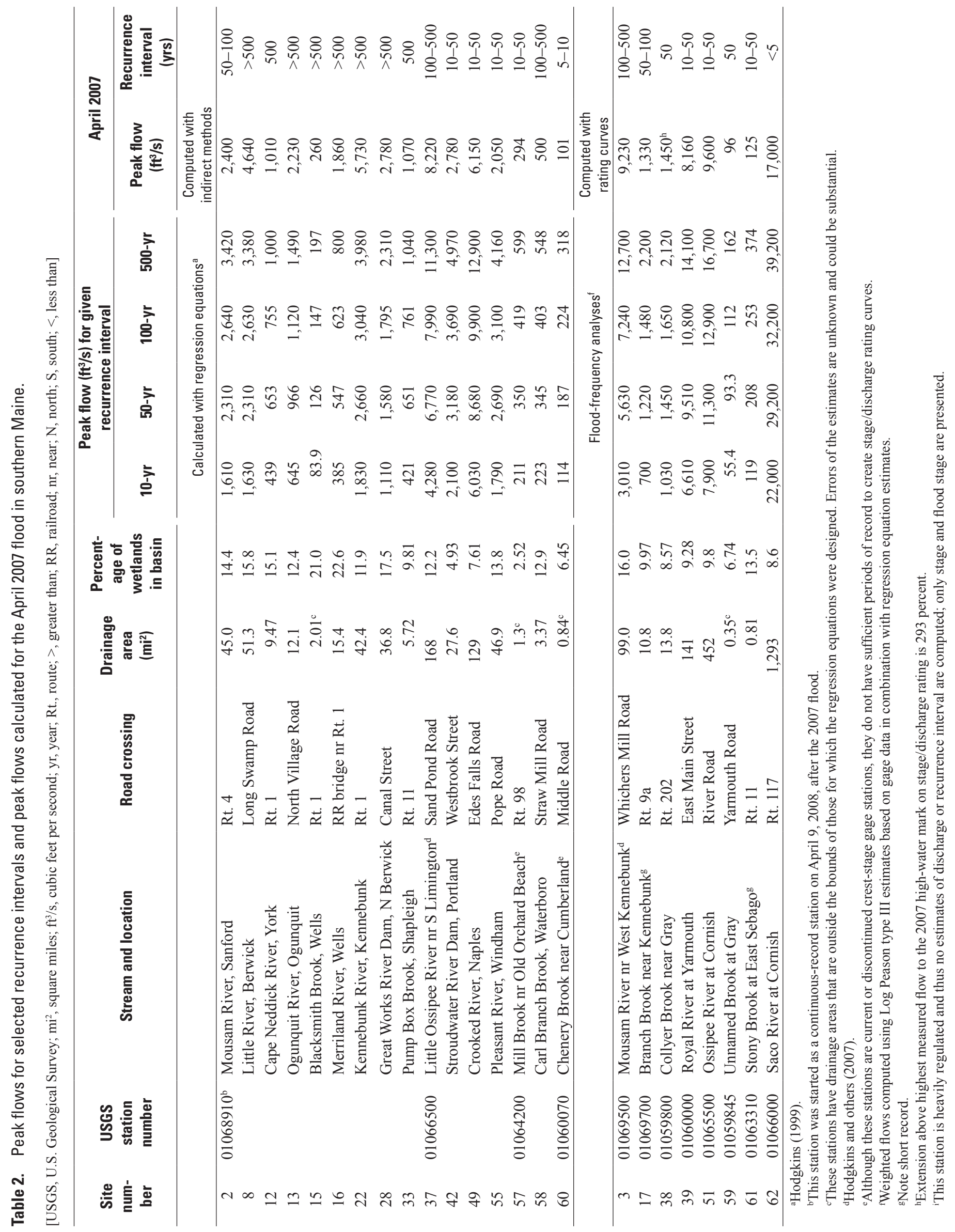




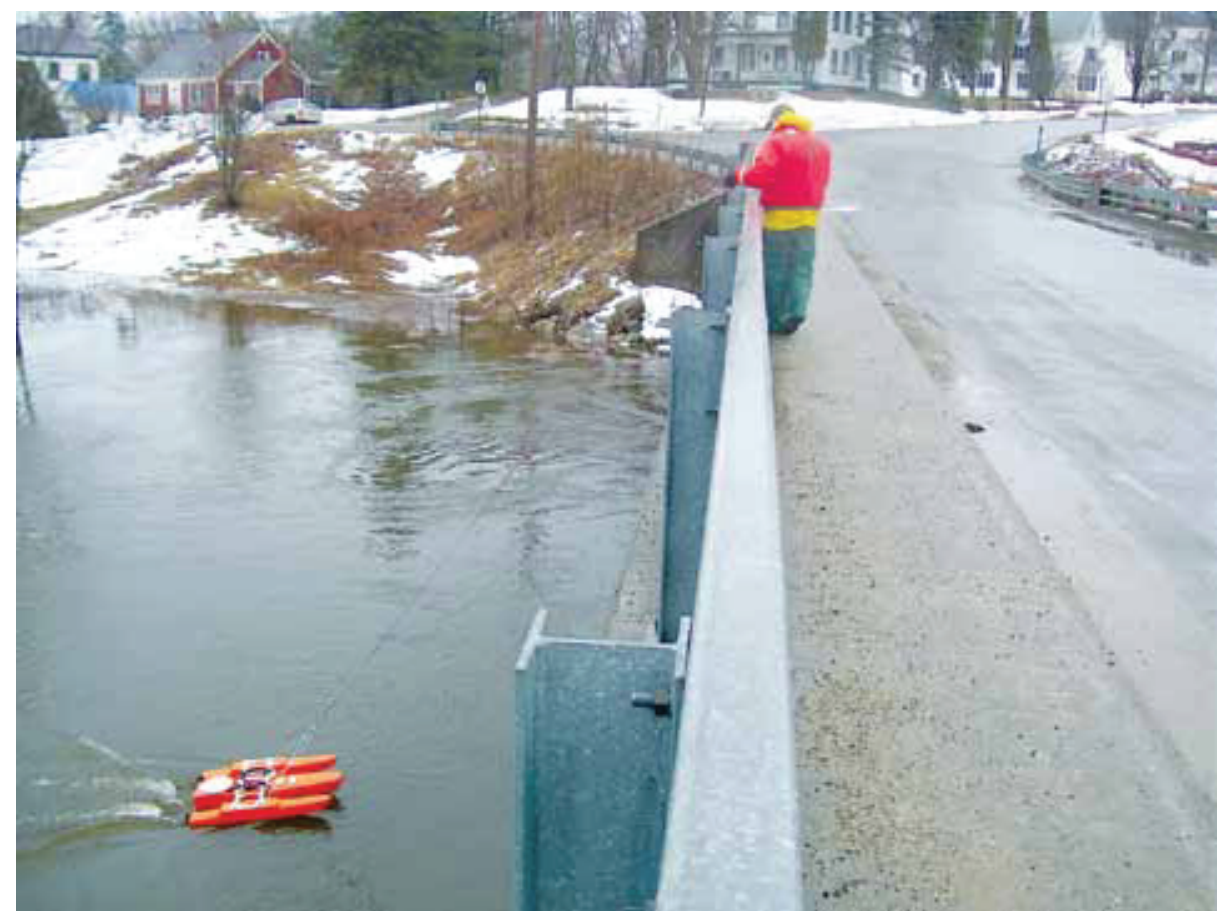

Figure 10. Streamflow measurement taken with acoustic Doppler current profiler on Nezinscot River, April 17, 2007, Turner, Maine.

\section{Determination of Peak Streamflows through Stage/Discharge Rating Curves}

The most reliable method for computing peak streamflows is the use of a calibrated and recently confirmed rating curve. The relation of stage to flow is controlled by a downstream reach or section of a channel referred to as a control. Depending on the stability of the river control at high flows, a rating can sometimes be extrapolated beyond its calibrated range. Historic rating curves can be used to determine peak discharges at inactive stations if there is evidence the site has a stable control and, therefore, a rating curve that is still accurate and applicable. To develop a rating curve, available streamflow measurements and corresponding stream elevations at a site are analyzed and plotted and a best-fit relation between them is developed (Rantz and others, 1982).

Peak streamflows were computed at two locations from current rating curves using peak water-surface elevations obtained from continuous-record streamflow-gaging stations in operation during the April 2007 flood. The Saco River at Cornish (USGS station number 01066000) and Stony Brook at East Sebago (USGS station number 01063310) peaked at 17,000 and $125 \mathrm{ft}^{3} / \mathrm{s}$, respectively (table 2). Times, dates, and elevations associated with these peak streamflows are discussed in the section (Peak Water-Surface Elevations) above. A peak flow of $96 \mathrm{ft}^{3} / \mathrm{s}$ was obtained from the crest-stage gaging station Unnamed Brook at Gray (USGS station number 01059845) in operation during the April 2007 flood.
HWMs were used to estimate peak streamflows at several discontinued sites that had stable rating curves: Mousam River near West Kennebunk (USGS station number 01069500), Branch Brook near Kennebunk (USGS station number 01069700), Collyer Brook near Gray (USGS station number 01059800), Royal River at Yarmouth (USGS station number 01060000), and Ossipee River at Cornish (USGS station number 01065500) (table 2). There is uncertainty with the rating curve and the estimated peak streamflow of $1,450 \mathrm{ft}^{3} / \mathrm{s}$ at Collyer Brook near Gray because the curve was extended well above the highest streamflow measurement.

\section{Determination of Peak Streamflows through Hydraulic Modeling using Indirect Methods}

Peak streamflow was determined at the remaining 16 sites using indirect methods based on hydraulic modeling (Benson and Dalrymple, 1967; Matthai, 1967). One of the sites was an active crest-stage gaging station (Chenery Brook at Cumberland) and one was a discontinued crest-stage gaging station (Mill Brook near Old Orchard Beach); however, these stations had insufficient data from which to develop stage/ discharge rating curves, and therefore, use of indirect methods was required to compute peak streamflows. Hydraulic models developed as a part of the May 2006 flood investigation to compute peak streamflows (Stewart and Kempf, 2008) were used at five of the sites. 
The contraction of a stream channel by a bridge crossing can create an abrupt drop in water-surface elevation. The geometry of the channel and bridge, estimates of the slope downstream of the contraction, and roughness values are defined through field surveys and entered into the one-dimensional steady-flow water-surface-profile computation component of the U.S. Army Corps of Engineers step-backwater computer program HEC-RAS (U.S. Army Corps of Engineers, 2004). Peak streamflows were determined to be those that resulted in computed water-surface elevations from the HEC-RAS model that matched elevations of HWMs observed in the field (table 2).

\section{Flow-Frequency Analyses}

Peak streamflows from the April 2007 flood were compared to peak flows with standard recurrence intervals at the same location to determine the approximate recurrence intervals of the April 2007 peak flows. The recurrence interval is the average period of time between peak flows greater than or equal to a specified magnitude. For example, the 50-year peak flow is the flow that would be exceeded or equaled on average of once in 50 years. This does not imply that flooding will happen at regular intervals. Two 50-year peak flows could occur in consecutive years or even the same year. In contrast, a second 50-year peak flow might not occur for another 100 years. The reciprocal of the recurrence interval is called the annual exceedance probability - that is, the probability that a given peak flow will be exceeded or equaled in any given year. For example, the annual exceedance probability of the 50 -year peak flow is 0.02 . In other words, there is a 2-percent chance that the 50-year peak flow will be exceeded or equaled in any given year. All estimates of recurrence interval have uncertainty associated with them. The uncertainty generally increases as the recurrence interval increases, especially at sites where the period of record is much shorter than the recurrence interval (Interagency Advisory Committee on Water Data, 1982). As the length of record at a streamflowgaging station increases, the computed recurrence intervals may become more accurate. Stationarity (the absence of trends) in peak streamflows over time is an assumption of the flood-flow-frequency techniques used in these analyses (Interagency Advisory Committee on Water Data, 1982). The validity of this assumption is currently being investigated for peak flows in Maine (G. Hodgkins, U.S. Geological Survey, personal commun., 2008).

The 10-, 50-, 100-, and 500-year peak flows for streamflow-gaging stations with at least 10 years of peak-flow data were calculated using the guidelines in Bulletin 17B of the Interagency Advisory Committee on Water Data (1982). A logPearson type-3 frequency analysis was fitted to the logarithms (base 10) of the observed annual peak flows at each station with sufficient data. Flood-frequency estimates from Hodgkins (1999) were updated for this report with an additional 9 years of data where available for stations in southern Maine.
The 2007 peak on the Mousam River in West Kennebunk (USGS station number 01069500 ) of $9,230 \mathrm{ft}^{3} / \mathrm{s}$ is the highest known peak for that site since 1939, although only the years from 1939 to 1984 were gaged continuously. The estimated peak at Collyer Brook near Gray (USGS station number 01059800) of $1,450 \mathrm{ft}^{3} / \mathrm{s}$ is the highest known peak during the 20 years of continuous monitoring from 1965 through 1982 and from 1999 through 2000, but it is unknown whether this peak was exceeded during the period from 1983 through 1998 or from 2001 through 2006. The peak discharge of $125 \mathrm{ft}^{3} / \mathrm{s}$ on Stony Brook at East Sebago (USGS station number 01063310) was the second-highest peak in 10 years of record; the peak of $130 \mathrm{ft}^{3} / \mathrm{s}$ on September 17, 1999, was the highest (U.S. Geological Survey, 2008).

The Salmon Falls River at Milton (USGS station number 01072100) had a peak flow of 5,500 ft's d during the April 2007 flood with an estimated recurrence interval of 25-50 years (Flynn, 2008). Several New Hampshire streamflow-gaging stations close to the Maine border had peak-flow recurrence intervals of between 100 and 500 years, including the Isinglass River at Rochester Neck Road near Dover (USGS station number 01072870) and the Oyster River near Durham (USGS station number 01073000) (Flynn, 2008).

Flow frequencies for sites without historical peak-flow data were calculated using the regression equations presented in Hodgkins (1999). These equations were developed using generalized least-squares regression procedures based on data from 70 USGS streamflow-gaging stations in Maine and eastern New Hampshire. The explanatory variables used in the equations were drainage area and percentage of basin covered by wetlands. Four of the sites at which flow frequencies were computed using the regression equations are outside the bounds for which the equations were designedBlacksmith Brook at Wells, Mill Brook near Old Orchard Beach, Unnamed Brook at Gray, and Chenery Brook at Cumberland. These sites all have drainage basins less than $3 \mathrm{mi}^{2}$, and therefore the accuracy of the estimates at these sites is unknown.

Recurrence intervals for peak streamflows at six of the streams studied as a part of this flood analysis were calculated to be greater than 500 years (table 2). April 2007 peak streamflows had recurrence intervals between 100 and 500 years at five sites, between 50 and 100 years at two sites, between 10 to 50 years at nine sites, and below 10 years at two sites. Generally, streams in York County had recurrence intervals greater than 100 years; the largest recurrence intervals were clustered around Wells and Kennebunk, Maine. Streams in Cumberland County generally had peak flows with recurrence intervals between 10 and 50 years (fig. 11).

For the 16 locations where peak flows were determined by indirect methods, historical streamflow records are not available. However, general comparison of the calculated peak flow to theoretical maximum floods is possible. Crippen and Bue (1977) determined envelope curves relating empirical maximum peak flows to drainage area to provide a guide for estimating the magnitude of maximum flood flows that 


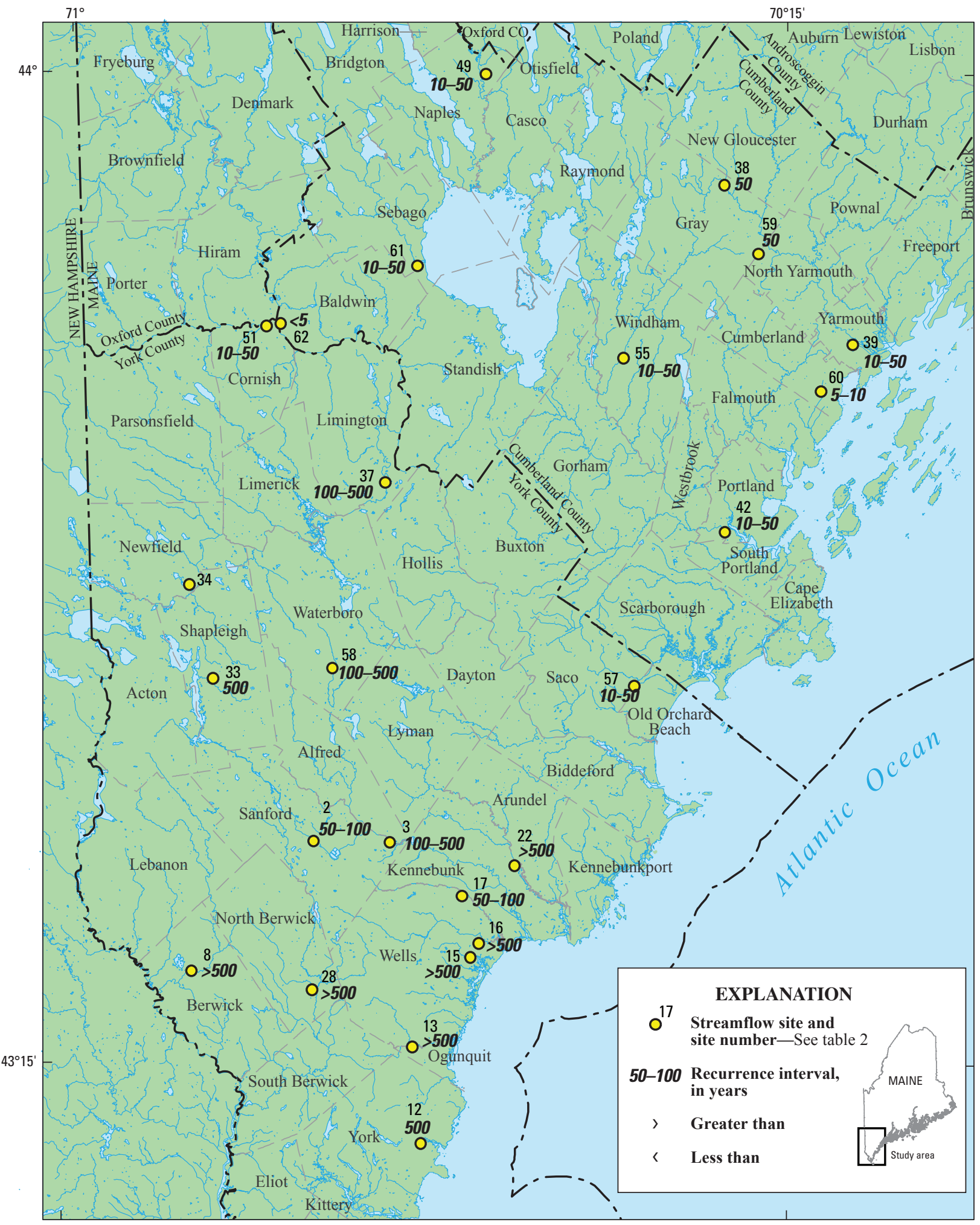

Base from U.S. Geological Survey and

Maine Office of Geographic Information System digital files,

North American Datum 83, Universal Transverse Mercator grid, Zone 19

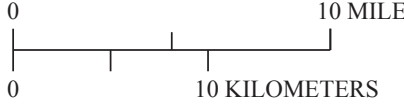

Figure 11. Peak streamflow recurrence intervals for selected sites, April 2007 flood, southern Maine. 
can be expected at a given site on a stream. The curves were developed by analyzing thousands of sites with recorded flood flows, and then using the sites with the most extreme flows to draw the envelope curves for 17 different regions in the United States. Maine is in region 1 (region 1 comprises Maine, Vermont, most of New Hampshire, most of Connecticut, western Massachusetts, and a small part of Rhode Island). The peak flows computed for this study plotted a similar distance below the Crippen region 1 envelope curve. None of the flood flows for the April 2007 flood in southern Maine reached or exceeded the potential maximum flood flow as defined by the Crippen and Bue (1977) envelope curves.

\section{Characteristics of the Flood in the Mousam River Watershed}

The Mousam River watershed (fig. 12) was heavily impacted by both the May 2006 flood and the April 2007 flood, and substantial damage to houses, roads, and culverts occurred both years. In addition, peak streamflows at the Mousam River near West Kennebunk (USGS station number 01069500) (table 2) were calculated to have greater than 100 -year recurrence intervals both years. The Mousam River watershed was investigated to determine the impact that the many small dams and reservoirs in the watershed had during the 2007 flood and to determine the potential impact that the dams and reservoirs could have during any event of this magnitude.

The analysis below compares the amount of water stored behind the dams in the Mousam River watershed to the amount of precipitation that fell throughout the watershed during the April 2007 flood. In addition, potential current storage and total storage available behind each dam prior to the April 2007 flood are calculated. Effective storage is defined in MEMA dam-inspection reports as storage below the spillway elevation that does not include dead storage (storage that cannot be released) (T. Fletcher, Maine State Dam Inspector, written commun., 2007). Because of the lack of comprehensive dam plans with surveyed gate and spillway elevations and incomplete water-level records, many assumptions were made to conduct this analysis. Without knowing the timing of the potential additional runoff and without surveying and modeling the dam outlets, the water elevations that the stored water could reach downstream of the dams cannot be accurately determined.

The Mousam River watershed has a drainage area of $117 \mathrm{mi}^{2}$ at the mouth and includes 13 dams with varying capacity to regulate flows and three additional historical dams that have been breached or are technically too small to be classified as dams (table 3 ). Thirteen dams control 1,420 million $\mathrm{ft}^{3}$ of effective storage (T. Fletcher, Maine State Dam Inspector, written commun., 2007). Five of the dams are on the west branch of the Mousam River in Shapleigh and Sanford; one is on the Middle Branch Mousam River in
Alfred; two are on Littlefield River (the eastern tributary to the Mousam River) in Alfred; and five are on the main stem of the Mousam River downstream of Estes Lake (fig. 12). Only 3 of the 13 reservoirs have effective storage capacities over 100 million $\mathrm{ft}^{3}$ - Square Pond, Mousam Lake, and Estes Lake - and another 2 have effective storage capacity between 50 and 100 million $\mathrm{ft}^{3}$ - Bunganut Pond, and the Pond above Old Falls Dam (table 3). Of these five reservoirs, only Square Pond and Mousam Lake are regulated by dams designated as flood-control dams in the dam-inspection reports (T. Fletcher, Maine State Dam Inspector, written commun., 2007). Although the remaining dams in the watershed are not designated flood-control dams, their design does allow for some flood control.

Although the USGS did not operate a continuous streamflow-gaging station in the Mousam River watershed in 2007, the USGS collected continuous streamflow-gaging data on the Mousam River near West Kennebunk on Whichers Mill Road (USGS station number 01069500) from October 1939 to September 1984. The rating curve for this station was assumed to be stable and was used to calculate a peak flow of $9,230 \mathrm{ft}^{3} / \mathrm{s}$ from documented HWMs near the discontinued station in April 2007 (site 3, table 2). In addition, HWMs and channel-geometry data were collected on the Mousam River at Route 4 near Sanford, Maine, in order to create a hydraulic model that was used to estimate a peak streamflow of 2,400 ft3 $/ \mathrm{s}$ at this site for the April 2007 flood (site 2, table 2). A continuous-record streamflow-gaging station was established on the Mousam River at Route 4 (USGS station number 01068910) in April 2008 and another station was reestablished on the Mousam River near West Kennebunk (USGS station number 01069500) in November 2008.

\section{Square Pond}

Square Pond has a drainage area of $4.3 \mathrm{mi}^{2}$, a surface area of $1.41 \mathrm{mi}^{2}$, a normal pool elevation of $523 \mathrm{ft}$ NAVD 88, and a total effective storage of 177 million $\mathrm{ft}^{3}$ (table 3). Square Pond is located at the headwaters of the main stem of the Mousam River in the northwestern portion of the watershed in Shapleigh, Maine (fig. 12). Square Pond Dam is at the northeast corner of Square Pond and it controls discharge of water into a canal. There is a natural outlet at the southwest corner of the lake, which is lower in elevation than the crest of the Square Pond Dam and is not regulated.

Square Pond Dam has a single 2- by 2-ft gate with an invert that is lower in elevation than the natural outlet, allowing for discharges into the canal. Although surveyed elevations were not available for Square Pond Dam, the dam operator indicated that the invert of the gate is at least $6 \mathrm{ft}$ below the top of a trash-rack grate and at least $10 \mathrm{ft}$ down from the top of the dam (M. Blouin, Sanford Dam Operator, personal commun., 2008). There are no flashboards or flood gates as part of this structure, although the Square Pond Dam is a designated flood-control dam. It is unlikely that water would overtop the dam, because water would flow out of the natural outlet before 


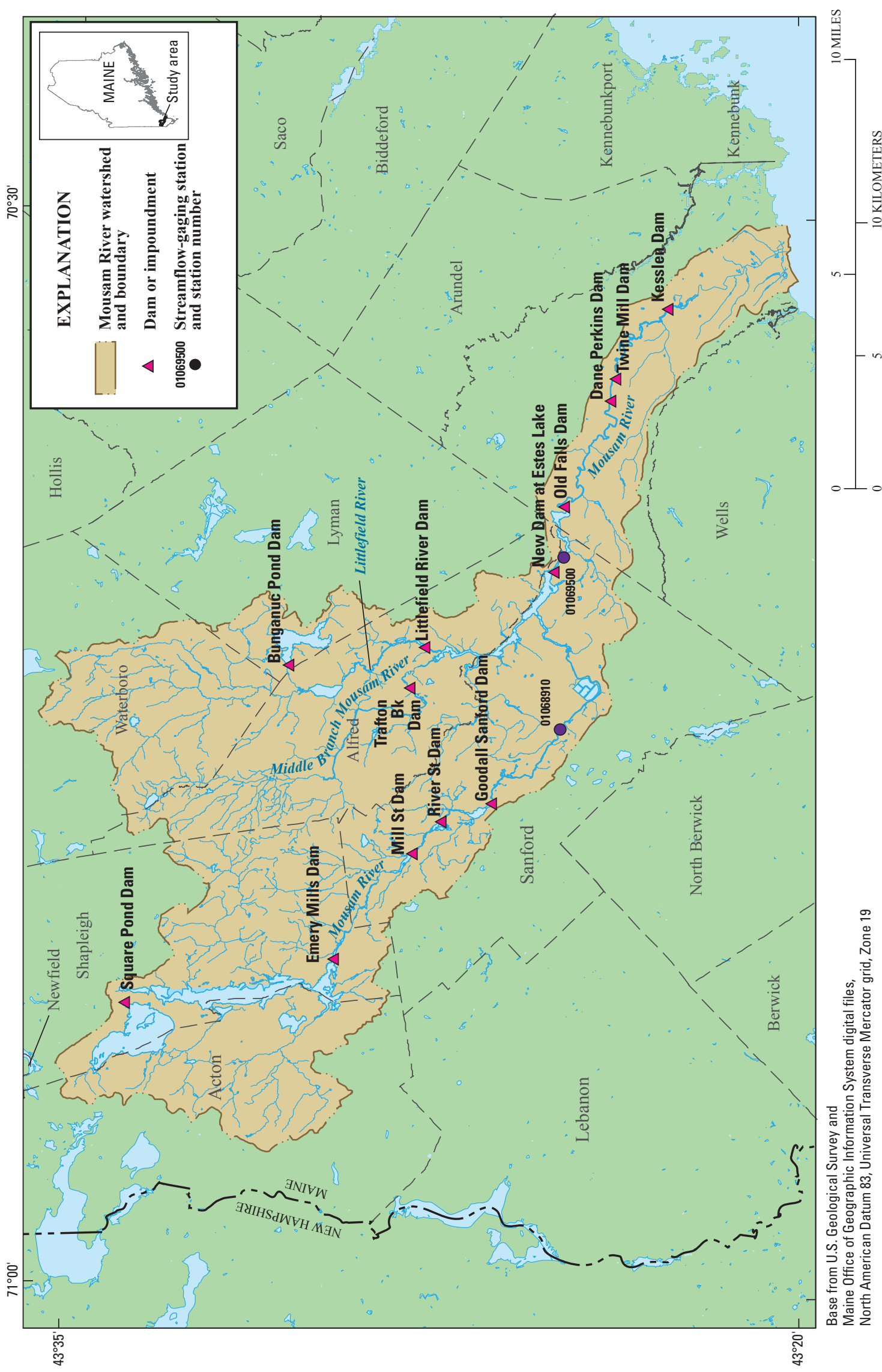

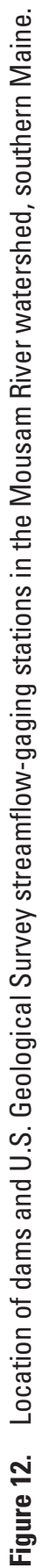




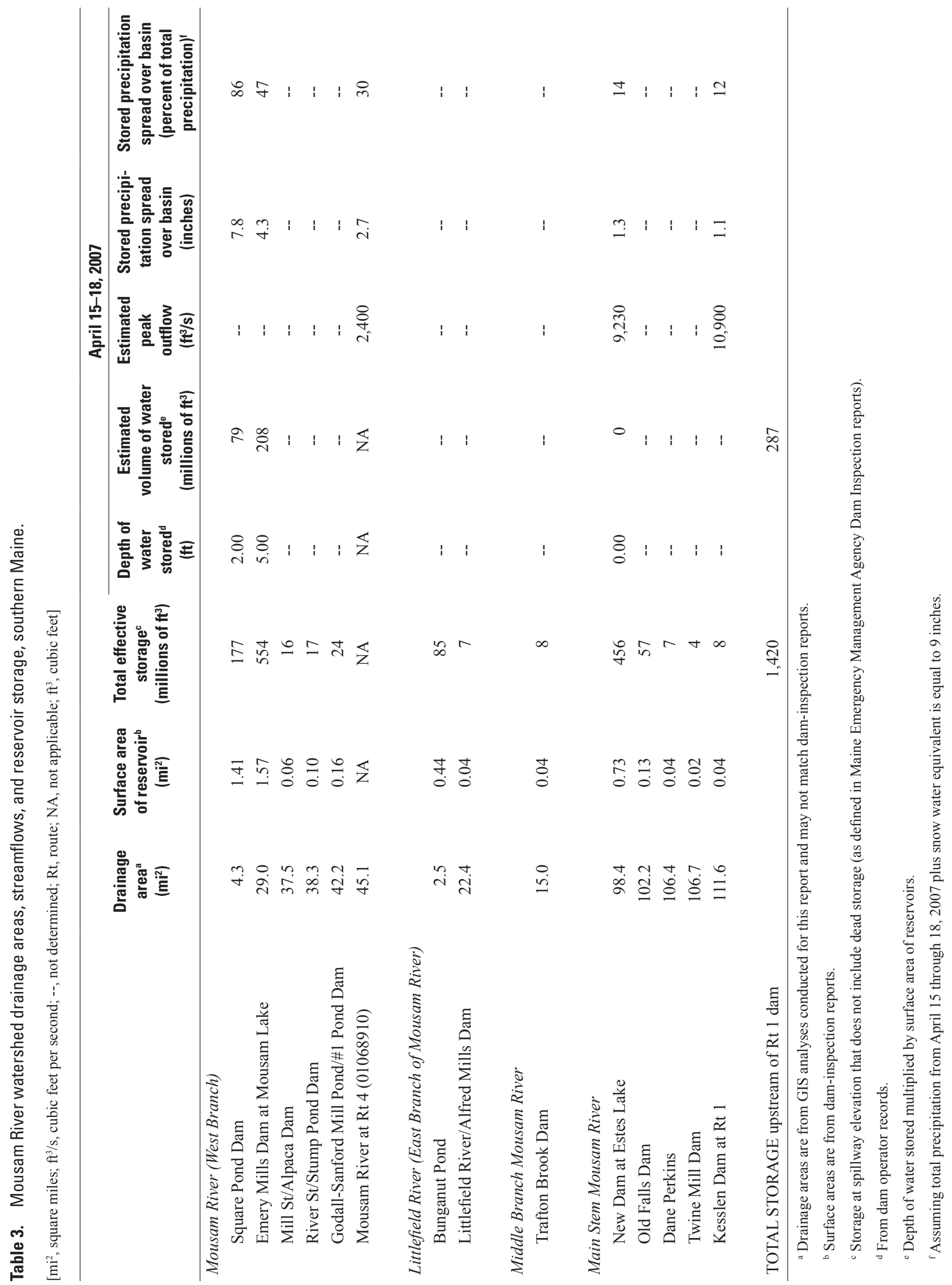


overtopping would occur. Square Pond has a large amount of effective storage, but very little dam-operator control.

Dam-operator records indicate that the gate on the Square Pond Dam had been fully open since the preceding fall (2006), and water levels had been roughly $21 \mathrm{in}$. below the top of the trash-rack grate from January 2007 through the beginning of April 2007. With the gate fully open throughout this period, the maximum amount of storage was maintained. Water levels rose from $20 \mathrm{in}$. below the grate to $8 \mathrm{in}$. below the grate between April 4 and 16, 2007, and then rose from 8 in. below the grate to $4 \mathrm{in}$. above the grate from April 16 through 18 (M. Blouin, Sanford Dam Operator, personal commun., 2008). For the purposes of these analyses, the assumption is made that most of this 2-ft rise occurred from April 15 through 18. Records at the Emery Mills Dam on Mousam Lake just downstream of Square Pond support this assumption because water levels in Mousam Lake did not rise from April 4 through 15, 2007 (see Emery Mills Dam at Mousam Lake). Although water did not overtop the dam during the April 2007 flood, water was flowing out of the natural outlet during this period. Flows and (or) water levels at the natural outlet are not recorded by the dam operator.

On the basis of the estimated 2-ft rise in the reservoir and a surface area of $1.41 \mathrm{mi}^{2}$, Square Pond stored approximately 79 million $\mathrm{ft}^{3}$ of water during the April 2007 flood. If water levels behind the dam could be drawn down to make all 177 million $\mathrm{ft}^{3}$ of potential effective storage available, a 100 -year inflow event could potentially be stored in Square Pond. This may not be possible during wet years with only a single 2 - by 2 -ft gate available to control water levels.

\section{Mousam Lake}

The Mousam Lake watershed has a drainage area of $29 \mathrm{mi}^{2}$ at Emery Mills Dam and includes Square Pond. Mousam Lake has a surface area of $1.57 \mathrm{mi}^{2}$, a normal pool elevation of $478 \mathrm{ft}$ NAVD 88 behind the dam, and a potential effective storage at the elevation of the spillway of 554 million $\mathrm{ft}^{3}$ (table 3 ). The dam has two 35 -inch diameter gates and an emergency spillway that is $57 \mathrm{ft}$ wide and has a capacity of 2,200 ft $3 / \mathrm{s}$. Emery Mills Dam, at the outlet of Mousam Lake, is a designated flood-control dam (T. Fletcher, Maine State Dam Inspector, written commun., 2007).

Water behind the Emery Mills Dam was 4 to $5 \mathrm{ft}$ below the level of the spillway throughout early April 2007. It rose from $4.75 \mathrm{ft}$ below the spillway to $3 \mathrm{in}$. above the spillway between April 15 and 18, 2007 (rain from the Patriots' Day Storm started on April 15). The Emery Mills Dam gates were partially open in the days preceding the flood and then were fully opened on April 18 during the flood (M. Blouin, Sanford Dam Operator, personal commun., 2008). The $5.0 \mathrm{ft}$ rise in Mousam Lake during the flood represents a volume of approximately 208 million $\mathrm{ft}^{3}$ of water with an assumed surface area of the lake of $1.57 \mathrm{mi}^{2}$ (table 3 ).

\section{Estes Lake}

The Estes Lake watershed has a drainage area of $98.4 \mathrm{mi}^{2}$ at New Dam, just downstream of where the Littlefield River, and the west and middle branches of the Mousam River converge. Estes Lake has a surface area of $0.73 \mathrm{mi}^{2}$, a normal pool elevation of $214 \mathrm{ft} \mathrm{NAVD} 88$ behind the dam, and a potential effective storage at the elevation of the spillway of 456 million $\mathrm{ft}^{3}$ (table 3). New Dam is a hydroelectric project dam on the main stem of the Mousam River in Kennebunk, Maine, and is located just upstream of the former USGS streamflow-gaging site at Whichers Mill Road (station number 01069500), and thus, flows calculated at Whichers Mill Road can be used to represent outflows from New Dam. Although the dam has two turbines with a combined hydraulic capacity of $320 \mathrm{ft}^{3} / \mathrm{s}$, there are no flood gates, and flashboards are not used; thus, there is limited capacity for altering the flow over the crest of the dam during times of extreme high flows (L. Loon, Ridgewood Power, personal commun., 2008). New Dam is not designated as a flood-control dam and even if all the effective storage in Estes Lake was available at the time of the April 2007 flood, it is unlikely that the timing and magnitude of the peak outflow could have been controlled appreciably through dam operation.

Water was flowing over the crest of the dam throughout April 2007, indicating that all effective storage was full at the time of the Patriots' Day Storm (L. Loon, Ridgewood Power, personal commun., 2008). Although New Dam operators typically have a goal of maintaining water levels $1 \mathrm{ft}$ below the dam crest during April, water has spilled over the crest of the dam during April in every year from 2004 to 2008. This suggests that the ability to draw this dam down through regulation during normal spring periods is minimal.

\section{Combined Impact of Dams}

Approximately 20 percent of total effective storage in the Mousam River watershed was available preceding the April 2007 flood and was used during the event. The storage of this water may have attenuated peak flows, especially on the west branch of the Mousam River where most of the effective storage was available. The estimate of peak streamflow was 2,400 or $53 \mathrm{ft}^{3} / \mathrm{s}$ per square mile in April 2007 on the west branch of the Mousam River at Route 4 in Sanford-yet it was 9,230 or $93 \mathrm{ft}^{3} / \mathrm{s}$ per square mile in April 2007 on the main stem of the Mousam River at Whichers Mill Road (station number 01069500). This suggests that flood runoff was indeed stored in the headwaters of the west branch of the Mousam River in Square Pond and Mousam Lake.

An estimated 9 in. of rain and snow water equivalent fell or melted throughout the Mousam watershed during the Patriots' Day Storm (see section Precipitation Amounts) above. Only Square Pond and Mousam Lake had any substantial storage available preceding the April 2007 flood and stored 79 and 208 million $\mathrm{ft}^{3}$ of water, respectively, for 
a total of 287 million $\mathrm{ft}^{3}$ of water (table 3). If the 79 million $\mathrm{ft}^{3}$ of water stored in Square Pond is spread evenly across the whole watershed upstream of Square Pond Dam, it represents 7.8 of the 9 in. (or 86 percent of the total precipitation) that fell or melted upstream of this location. Water stored above Emery Mills Dam (287 million $\mathrm{ft}^{3}$ of water in Square Pond and Mousam Lake combined) represents 4.3 in. (or 47 percent of the 9 in. that fell or melted) if it is spread evenly across the watershed upstream of Emery Mills Dam. Although when this additional water would have run off had it not been stored is unknown - and thus, its resultant increase in flow is unknown - this is water that potentially could have added to peak streamflows downstream in the watershed.

No appreciable amount of water was stored in the reservoirs downstream of the Emery Mills Dam during the storm. Estimates of the percentage of water stored to water that fell (or melted) throughout the remainder of the watershed can be obtained by dividing the 287 million $\mathrm{ft}^{3}$ of water stored above Emery Mills Dam by the drainage area at each location. If the stored water is spread evenly throughout the basin at New Dam and at Kesslen Dam at Route 1, the 287 million $\mathrm{ft}^{3}$ of water stored represents 1.3 and 1.1 in. of water (or 14 and 12 percent of the total $9 \mathrm{in}$.), respectively.

None of the dams in the Mousam watershed have large flood-release gates that would allow for increases of flow during a flood event appreciably above the flow that would occur naturally during a high-flow event, once the spillway was overtopped. There is a great deal of effective storage in the watershed that could potentially be made available preceding a large flood event assuming the event could be predicted days to weeks in advance, and assuming streamflows preceding the event were not so large as to prevent the lowering of reservoir levels. Water-resource managers commonly need to balance flood control with potentially competing water-use interests such as hydraulic capacity, summer low flows, wildlife habitat, and recreation. If all effective storage in the Mousam River watershed were made available preceding an event, flood flows equivalent to or less than a 100-year event could potentially be attenuated. This does not take into account the practicality of maintaining large amounts of storage, and as noted above for New Dam at Estes Lake, it was not possible to maintain any available storage during the month of April in any of the 4 years preceding the 2007 event because of consistently high amounts of spring runoff during those years. Even where effective storage was not available preceding this event, natural or uncontrollable storage (storage above the dam-crest elevations) in the reservoirs throughout the Mousam River watershed likely attenuated peak flows.

\section{Historical Floods in Southern Maine}

Minimal historical peak-flow data are available for southern Maine, especially York County, because there are so few continuously operated streamflow-gaging stations with long periods of record. Riverine floods with recurrence intervals
Table 4. April 2007 peak flows in comparison to May 2006 peak flows in southern Maine.

$\left[\mathrm{ft}^{3} / \mathrm{s}\right.$, cubic feet per second]

\begin{tabular}{|c|c|c|c|}
\hline $\begin{array}{c}\text { Site } \\
\text { number }\end{array}$ & Stream and location & $\begin{array}{c}2006 \\
\text { Peak flow } \\
\left(\mathrm{ft}^{3} / \mathrm{s}\right)\end{array}$ & $\begin{array}{c}2007 \\
\text { Peak flow } \\
\left(\mathrm{ft}^{3} / \mathrm{s}\right)\end{array}$ \\
\hline 3 & $\begin{array}{l}\text { Mousam River near West } \\
\text { Kennebunk }\end{array}$ & 6,100 & 9,230 \\
\hline 8 & Little River, Berwick & 3,390 & 4,640 \\
\hline 12 & Cape Neddick River, York & 2,250 & 1,010 \\
\hline 13 & Ogunquit River, Ogunquit & 3,110 & 2,230 \\
\hline 15 & Blacksmith Brook, Wells & 473 & 260 \\
\hline 16 & Merriland River, Wells & 2,240 & 1,860 \\
\hline 17 & Branch Brook near Kennebunk & 1,500 & 1,330 \\
\hline 61 & Stony Brook at East Sebago & 40 & 125 \\
\hline 62 & Saco River at Cornish & 14,900 & 17,000 \\
\hline
\end{tabular}

greater than 50 years occurred in south-central and southwestern Maine in March of 1936 and 1953, respectively (Maloney and Bartlett, 1991). More recent floods occurred in southern Maine in 1987, 1996, and 2006 (Fontaine and Nielsen, 1994; Hodgkins and Stewart, 1997; Stewart and Kempf, 2008). Peak streamflows during 2006 and 2007 floods were generally greater than those in 1996 or 1987. Northeasters and hurricanes accompanied by high tides can cause coastal flooding and erosion in addition to riverine flooding. Major coastal flooding of unknown recurrence intervals occurred in southern Maine during November in 1945, 1963, and 1968, and during February in 1972 and 1978 (Federal Emergency Management Agency, 1982-2003).

Extreme flooding events with recurrence intervals greater than 100 years occurred in the springs of 2006 and 2007 in southern Maine. Both storms were centered in coastal York County. Of the nine sites at which estimates of peak streamflow were obtained for both floods, flows were greatest in 2006 at Merriland River in Kennebunk (site 16, table 2), Ogunquit River in Ogunquit (site 13, table 2), Blacksmith Brook in Wells (site 15, table 2), Cape Neddick River in York (site 12, table 2), and Branch Brook near Kennebunk (site 17, table 2). These sites are all located close to Kennebunk, Maine, and the coast. Sites somewhat farther from the coast such as Little River in Berwick (site 8), Stony Brook at East Sebago (site 61, table 2), Saco River at Cornish (site 62, table 2), and Mousam River near West Kennebunk (site 3, table 2) had higher peak flows in 2007 than in 2006 (table 4). 


\section{Comparison of the April 2007 Flood Data to Flood Insurance Studies}

Flood Insurance Studies (FISs) published by FEMA provide 10-, 50-, 100-, and 500-year recurrence-interval streamflows and water-surface elevations for many flooding sources affected by the April 2007 flood in southern Maine. In many cases, flood-frequency data calculated for this report (table 2) differed from flood-flow-frequency data published in the applicable FIS (Federal Emergency Management Agency, 1982-2003) (table 5). Differences show where updated techniques and up to 30 years of additional data can change estimated statistical peak flows for selected recurrence intervals. Streamflows and peak water-surface elevations observed during the April 2007 flood are presented in table 5 alongside streamflows and water-surface elevations from the same locations compiled from the appropriate FIS. This table identifies sites at which theoretical FIS water-surface-elevation profiles are not consistent with the peak water-surface elevation observed in April 2007, given the peak streamflow observed in April 2007. Theoretically, the recurrence interval for the peak water-surface elevation and the recurrence interval for the peak streamflow from the same event at the same location should be the same.

Peak flows with 10-, 50-, 100- and 500-year recurrence intervals were calculated for selected locations in southern Maine using log-Pearson type-3 frequency analyses where historical streamflow-gaging data were available and regression equations where historical data were not available (table 2). At 8 of the 15 sites, 100-year recurrence-interval streamflows calculated for this project were at least 10 percent smaller than those in the current FIS. For Mousam River, Ogunquit River, Merriland River, Kennebunk River, Stroudwater River, and Crooked River, drainage-area adjustments had to be applied to the flows published in the current FIS before they could be compared to peak flows calculated for this report (Federal Emergency Management Agency, 1982-2003). FIS profiles were adjusted from NGVD 29 to NAVD 88 at all sites in order to make the comparison with 2007 peak elevations surveyed in NAVD 88.

If flow frequencies were computed with log-Pearson type- 3 frequency analyses for both this work and the current FIS, differences could be the result of the length of record used in the analyses. For example, 30 years of additional data now available at Saco River at Cornish (USGS station number 01066000) resulted in 50-, 100-, and 500-year flows calculated for this report (table 2) that were at least 10 percent smaller than the 50-, 100-, and 500-year flows in the current FIS at this location (table 5). At Ossipee River at Cornish (USGS station number 01065500), the 500-year flow calculated for this report (table 2) was 12 percent less than the 500 -year flow in the current FIS (table 5).

FISs typically have flow frequencies calculated with an older set of equations (Morrill, 1975). Updated equations (Hodgkins, 1999) developed with an additional 25 years of data and improved statistical techniques were used to calculate flow frequencies for this project. Blacksmith Brook in Wells (site 15, fig. 2) and Merriland River in Wells (site 16, fig. 2), both had streamflows at all recurrence intervals calculated with new regression equations (Hodgkins, 1999) that were at least 50 percent smaller than flows in the current FIS calculated with the older regression equations (Morrill, 1975) (table 5). An improved drainage-area calculation at Blacksmith Brook could have been part of the reason for the large change. Peak flows for the 100-year recurrence intervals at Ogunquit River in Ogunquit (site 13, fig. 2) and Cape Neddick River in York (site 12, fig. 2) calculated with the newer equations by Hodgkins (1999) were 31 and 21 percent less than the 100-year recurrence interval peak flows in the FISs calculated with the equations developed by Morrill (1975).

For many current FISs, the Natural Resources Conservation Service (NRCS) TR-20 theoretical rainfall-runoff method (Pilgrim and Cordery, 1993) was used to generate flowfrequency data. Flows for the 100 -year recurrence interval calculated with the equations developed by Hodgkins (1999) at the Great Works River Dam at Route 9 (site 28, fig. 2) were 24 percent less than the 100 -year recurrence-interval flow in the FIS calculated with the NRCS TR-20 model.

Estimates for flows of selected recurrence intervals at the Little Ossipee River near South Limington (USGS station number 01066500, site 37, fig. 2) and the Mousam River near Kennebunk (USGS station number 01069500, site 3, fig. 2) were calculated using a traditional log-Pearson type- 3 frequency analysis and an NRCS TR-20 model for the respective FISs. Flow-frequency data at both of these stations were updated by use of the Expected Moments Algorithm (EMA) developed by Cohn and others (1997) and analyses in Hodgkins and others (2007) in order to better accommodate historical peak-flow data outside the period of record. The 100-year flow at the Little Ossipee River was 10 percent less and the estimate of the 100-year flow at the Mousam River was 85 percent greater using the EMA.

At Mousam River at Sanford (site 2, fig. 2), Little Ossipee River near South Limington (site 37, fig. 2), Royal River at Yarmouth (site 39, fig. 2), Blacksmith Brook at Wells (site 15, fig. 2), and Ogunquit River in Ogunquit (site 13, fig. 2), the observed water-surface elevations (determined from HWMs) from the April 2007 flood were bracketed by elevation profiles with higher than expected recurrence intervals given the observed peak streamflows and modeled elevations in the FIS. The computed water-surface elevations from the April 2007 flood at the Great Works River Dam in North Berwick (site 28, fig. 2) were bracketed by elevation profiles with the same recurrence intervals as would be expected given observed peak streamflows and modeled elevations. At the Stroudwater River Dam in Portland (site 42, fig. 2), the Merriland River in Wells (site 16, fig. 2), the Kennebunk River in Kennebunk (site 22, fig. 2), and Collyer Brook at Gray (site 38, fig. 2), observed watersurface elevations were bracketed by elevation profiles with the same recurrence interval as would be expected given 
क

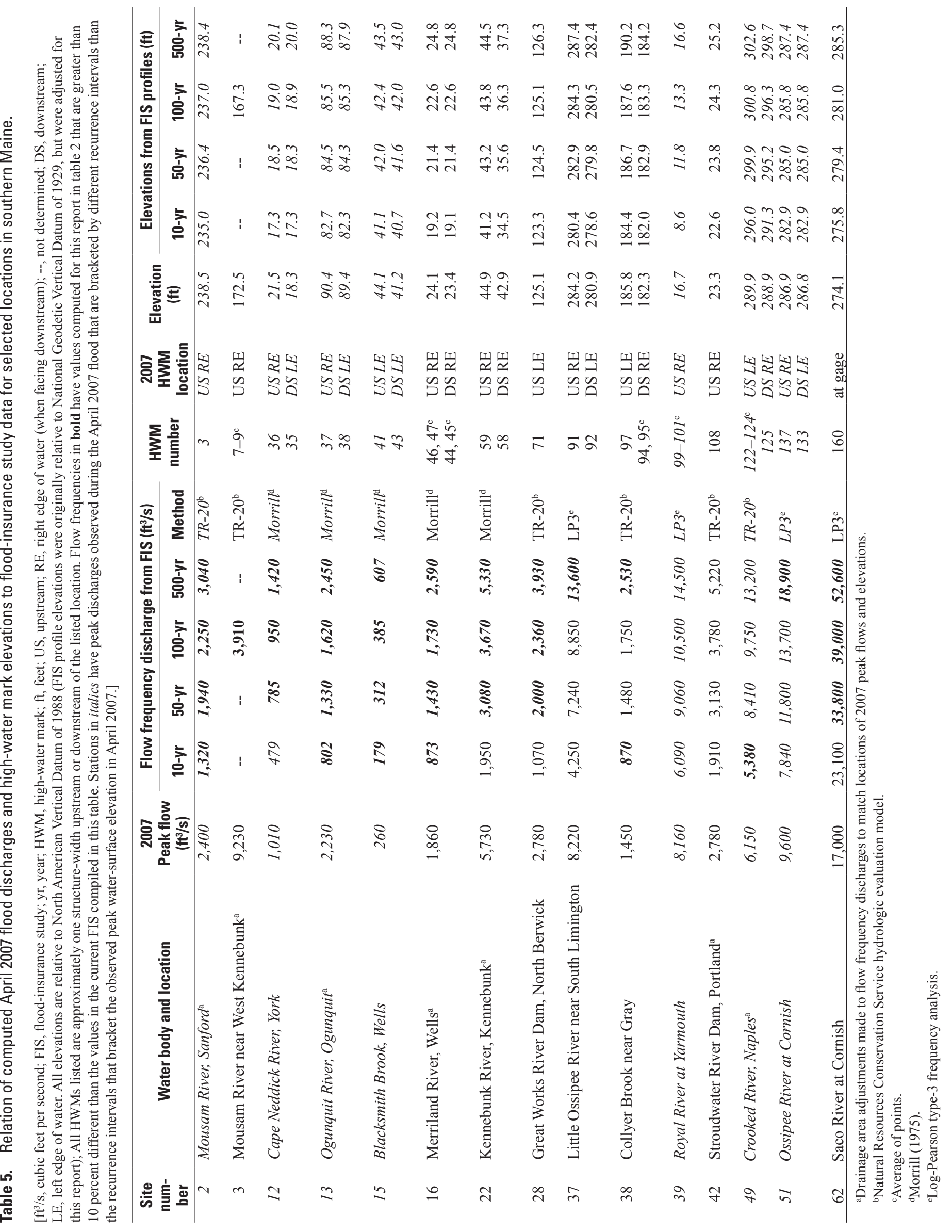


observed peak streamflows and modeled elevations in the FIS. However, models at Collyer Brook and at Merriland River showed less hydraulic drop through the bridges than was observed, and the FIS hydraulic model for Kennebunk showed a hydraulic drop greater than $7 \mathrm{ft}$ through the bridge than was observed during the April 2007 flood. Cape Neddick at York had a higher upstream peak elevation and a lower downstream peak elevation than was expected because the FIS hydraulic model showed almost no drop through the bridge, but the elevations observed in April 2007 showed a 3.2-ft drop through the bridge. Crooked River at Naples had watersurface elevations upstream and downstream of the bridge that were bracketed by recurrence intervals lower than would be expected given observed peak streamflows and water-surface elevations modeled in the FIS.

Discrepancies between elevations in the FIS models and elevations observed in April 2007 given a known observed flow have several possible causes. Discrepancies could be caused by the possible geomorphic or structural changes that may have taken place at the structure between the FIS analysis and the April 2007 flood. Another possible cause of elevation discrepancies is the error in determining the elevation from a profile plot in the FIS. Choosing the correct location and reading the correct elevation off the profile plot has error associated with it because of the linear interpolation used to develop the profiles between surveyed cross sections and because of the plot scale. The amount of the error is dependent on the rate of change of the profile plot near the structure of interest. There is also error in determining field estimations of the HWM elevation, which can be estimated from a single HWM or the average of up to three different HWMs. In addition, hydraulic models from which elevations are obtained may not have been calibrated if there had not been a flood of that magnitude at that location during the period of record and prior to the current FIS. Data collected during and after the floods in 2006 and 2007 will allow for more accurate calibration of future hydraulic models.

\section{Summary and Conclusions}

The Patriots' Day Storm affected much of the northeastern United States from April 15 through 18, 2007. This report focuses on its impact in southern Maine. The storm was characterized by up to $8.5 \mathrm{in}$. of rain falling on top of a wet snowpack with up to 1 in. of additional water equivalentcausing waterways with fairly normal antecedent streamflow conditions to overtop their banks. The highest rainfall totals in Maine were in coastal York County. Streams in the western mountains of York and Cumberland Counties generally had peak streamflows with lower recurrence intervals than did streams closer to the coast.

Peak-streamflow recurrence intervals were determined at 24 locations and peak water-surface elevations at 63 locations following the April 2007 flood. Peak streamflows were determined with data from continuous-record streamflowgaging stations where available, and through hydraulic models where stations were not available. The flood resulted in peak streamflows with recurrence intervals greater than 100 years throughout most of York County, and recurrence intervals up to 50 years in Cumberland County. Peak flows at select recurrence intervals updated as a part of this study varied from less than 10 percent to greater than 100 percent different than those that would be expected from the current Federal Emergency Management Agency flood-insurance studies.

This was the second storm in 2 consecutive years to have streamflows with recurrence intervals greater than 100 years on many streams in York County. The April 2007 flood covered a greater geographical area in Maine than did the flood of May 2006 - extending into Cumberland County in some locations. It is possible to get storms 2 years in a row with large recurrence intervals; however, recurrence intervals greater than 100 years have a large amount of uncertainty associated with them, especially when the period of record at a site is short. As more data are collected and assumptions about the stationarity of flow frequencies are tested, estimated recurrence intervals may become more accurate.

The Mousam River watershed was one of the watersheds in southern Maine where recurrence intervals of streamflows were greater than 100 years in both May 2006 and April 2007. Initial calculations in the Mousam River watershed contain many assumptions because field surveying of the dams was not included as a part of these flood-routing analyses. Although limited storage was available on the west branch of the Mousam River preceding the April 2007 flood, many of the storage reservoirs on the main stem of the Mousam River were filled to capacity and had little effective storage available. Thirty percent of the total precipitation upstream of the Mousam River at Route 4 was stored, but only 14 percent of total precipitation upstream of New Dam at the outlet of Estes Lake was stored.

A major flooding event such as that of April 2007 provided an opportunity to compare current Flood Insurance Studies (FISs) to actual peak flows and water-surface elevations observed in the field. At 8 of the 15 locations where detailed FISs were available, streamflows with 100-year recurrence intervals calculated for this report were at least 10 percent smaller than those in the current (2008) FIS, and at 2 of the 15 locations, flows were over 60 percent smaller because of additional data or newer regression equations. At 2 of the 15 locations (both on the Mousam River), peak flows with 100-year recurrence intervals were more than 10 percent higher than those in the current FIS as a result of new methods.

In many cases, current FIS models had not been calibrated to an actual flood and had peak water-surface elevations with different recurrence intervals than those of the peak streamflows measured during the April 2007 flood. Surveyed elevations and flows calculated after the 2007 event allowed for an independent check of the hydraulic models in the current FISs. Observed water-surface elevations determined 
from high-water marks resulting from the April 2007 flood were bracketed by elevation profiles with the same recurrence intervals as the recurrence intervals bracketing the observed peak streamflows at seven sites, with higher elevation-profile recurrence intervals than streamflow recurrence intervals at six sites, and with lower elevation-profile recurrence intervals than streamflow recurrence intervals at one site. Elevations and flows documented in this report can be used to calibrate future hydraulic models.

\section{Acknowledgments}

The author would like to thank Thomas Hawley from the National Weather Service (NWS) for providing meteorological data for this report and Tony Fletcher from the Maine Emergency Management Agency (MEMA) for providing information regarding the Mousam River dams. The following USGS employees provided substantial help by collecting the field data for this report: Joshua P. Kempf, Laura E. Flight, Lance H. Chapman, and Garrett E. Luszczki.

\section{References Cited}

Benson, M.A., and Dalrymple, Tate, 1967, General field and office procedures for indirect discharge measurements: U.S. Geological Survey Techniques of Water-Resources Investigations, book 3, chap. A1, 30 p.

Cohn, T.A., Lane, W.L., and Baier, W.G., 1997, An algorithm for computing moments-based flood quantile estimates when historical flood information is available: Water Resources Research, v. 33, no. 9, p. 2089-2096.

Crippen, J.R., and Bue, C.D., 1977, Maximum floodflows in the conterminous United States: U.S. Geological Survey Water-Supply Paper 1887, 52 p.

Federal Emergency Management Agency, 1982-2003, Flood Insurance Studies, Towns of Cornish, Gray, Kennebunk, Naples, North Berwick, Ogunquit, Portland, Sanford, South Berwick, South Limington, Wells, Yarmouth, York, York County, Maine: Washington D.C., variously paged.

Flynn, R.H., 2008, Flood of April 2007 in New Hampshire: U.S. Geological Survey Scientific Investigations Report 2008-5120, 53 p.

Fontaine, R.A., and Nielsen, J.P., 1994, Flood of April 1987 in Maine: U.S. Geological Survey Water-Supply Paper 2424, $50 \mathrm{p}$.
Hodgkins, G.A., 1999, Estimating the magnitude of peak flows in Maine for selected recurrence intervals: U.S. Geological Survey Water-Resources Investigations Report 99-4008, 45 p.

Hodgkins, G.A., and Stewart, G.J., 1997, Flood of October 1996 in southern Maine: U.S. Geological Survey WaterResources Investigations Report 97-4189, 28 p.

Hodgkins, G.A., Stewart, G.J., Cohn, T.A., and Dudley, R.W., 2007, Estimated magnitudes and recurrence intervals of peak flows on the Mousam and Little Ossipee Rivers for the Flood of April 2007 in southern Maine: U.S. Geological Survey Open-File Report 2007-1146, 13 p.

Interagency Advisory Committee on Water Data, 1982, Guidelines for determining flood flow frequency: Water Resources Council Bulletin 17B, 28 p.

Jensenius, J., Hawley, T., Turner, M., and Sturey, A., 2007, Coastal Storm April 15-23, 2007 (preliminary report), National Weather Service, Gray, Maine, April 27, 2007, $80 \mathrm{p}$.

Maine Cooperative Snow Survey, 2007, accessed August 1, 2007, at http://www.maine.gov/rfac/rfac_snow.shtml/.

Maloney, T.J., and Bartlett, W.P., Jr., 1991, Maine floods and droughts, in Paulson, R.W., Chase, E.B., Robert, R.S., and Moody, D.W. (compilers), 1991, National water summary 1988-99-Hydrologic events and floods and droughts: U.S. Geological Survey Water-Supply Paper 2375, p. 311-318.

Matthai, H.F., 1967, Measurement of peak discharge at width contractions by indirect methods: U.S. Geological Survey Techniques of Water-Resources Investigations, book 3, chap. A4, 44 p.

Morrill, R.A., 1975, A technique for estimating the magnitude and frequency of floods in Maine: U.S. Geological Survey Open-File Report 75-292, 44 p.

National Oceanic and Atmospheric Administration, 2002, Climatography of the United States No. 81, monthly station normals of temperature, precipitation, and heating and cooling degree days, 1971-2000: Region 17, Maine, 16 p.

National Weather Service, 2008, Gray/Portland: accessed May 21, 2008, at http://www.weather.gov/climate/local_ data.php?wfo=gyx

Pilgrim, D.H., and Cordery, I., 1993, Flood runoff, in Maidment, D.R., ed., Handbook of Hydrology: New York, McGraw-Hill Inc., p. 9.1-9.42. 
Rantz, S.E., and others, 1982, Measurement and computation of streamflow: U.S. Geological Survey Water-Supply Paper 2175 , v. 2, 631 p.

Stewart, G.J., and Kempf, J.P., 2008, Flood of May 2006 in York County, Maine: U.S. Geological Survey Scientific Investigations Report 2008-5047, 19 p.

U.S. Army Corps of Engineers, 2004, HEC-RAS River Analysis System Version 3.1.2: Hydrologic Engineering Center, accessed September 19, 2006, at http://www.hec.usace. army.mil/.

U.S. Geological Survey, 2008, National Water Information System: accessed May 21, 2008, at http://waterdata.usgs. gov/me/nwis/sw

Wilks, D.S., and Cember, R.P., 1993, Atlas of precipitation extremes for the northeastern United States and southeastern Canada: Cornell University, Northeast Regional Climate Center, $40 \mathrm{p}$. 
Table 1. Peak water-surface elevations for April 2007 flood in York and Cumberland Counties, Maine.

[HWM, high-water mark; Northings and Eastings referenced to Maine State Plane West, in feet relative to North American Datum of 1983; elevations, in feet, referenced to North American Vertical Datum of 1988; Rt., route; DS, downstream; LE, left edge of water (when facing downstream); US, upstream; RE, right edge of water; Rd., Road; St., Street; Ln., Lane; RR, railroad; Br., bridge; E Br, East Branch; site number, location shown on figure 2]

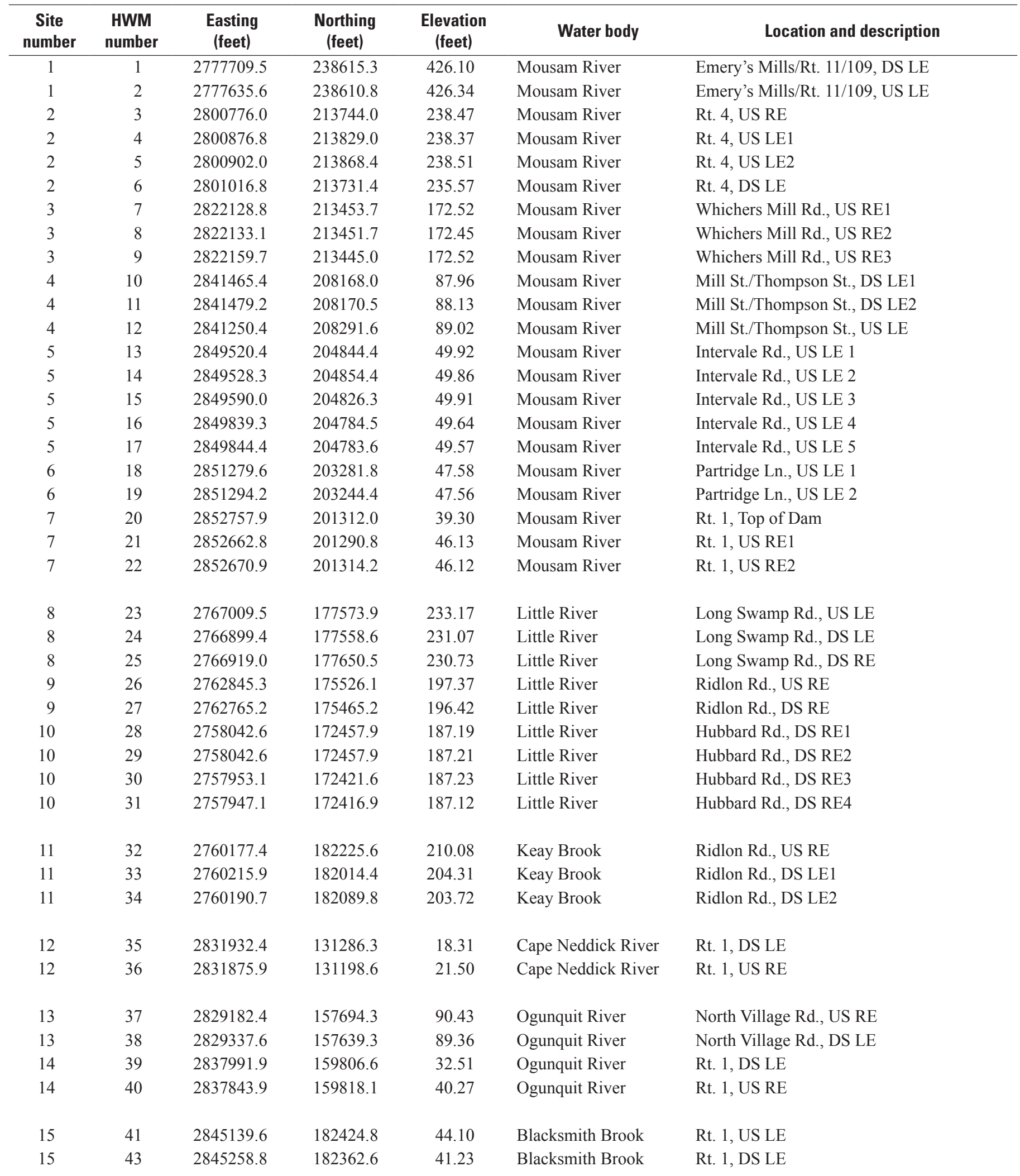


Table 1. Peak water-surface elevations for April 2007 flood in York and Cumberland Counties, Maine.-Continued

[HWM, high-water mark; Northings and Eastings referenced to Maine State Plane West, in feet relative to North American Datum of 1983; elevations, in feet, referenced to North American Vertical Datum of 1988; Rt., route; DS, downstream; LE, left edge of water (when facing downstream); US, upstream; RE, right edge of water; Rd., Road; St., Street; Ln., Lane; RR, railroad; Br., bridge; E Br, East Branch; site number, location shown on figure 2]

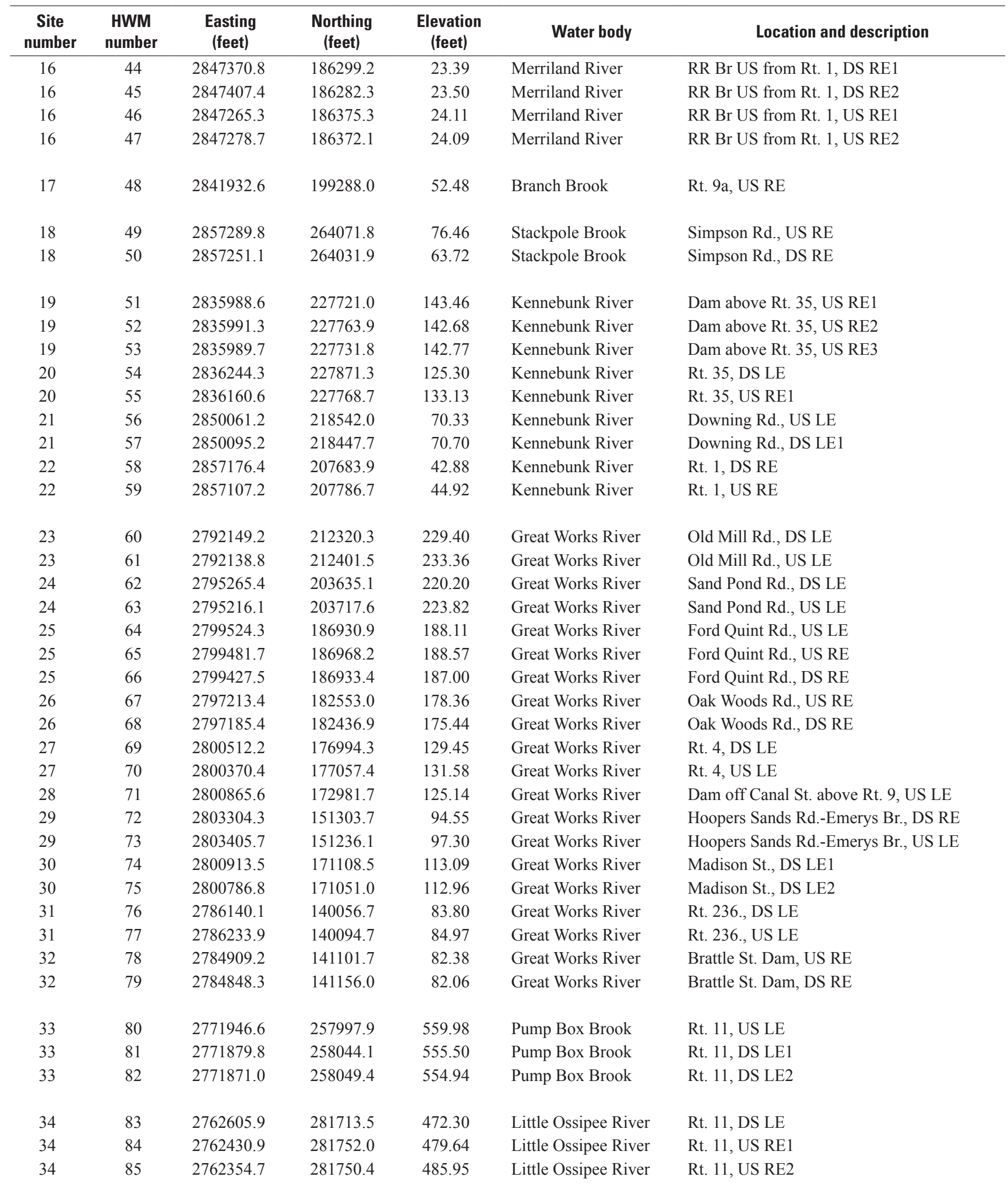


Table 1. Peak water-surface elevations for April 2007 flood in York and Cumberland Counties, Maine.—Continued

[HWM, high-water mark; Northings and Eastings referenced to Maine State Plane West, in feet relative to North American Datum of 1983; elevations, in feet, referenced to North American Vertical Datum of 1988; Rt., route; DS, downstream; LE, left edge of water (when facing downstream); US, upstream; RE, right edge of water; Rd., Road; St., Street; Ln., Lane; RR, railroad; Br., bridge; E Br, East Branch; site number, location shown on figure 2]

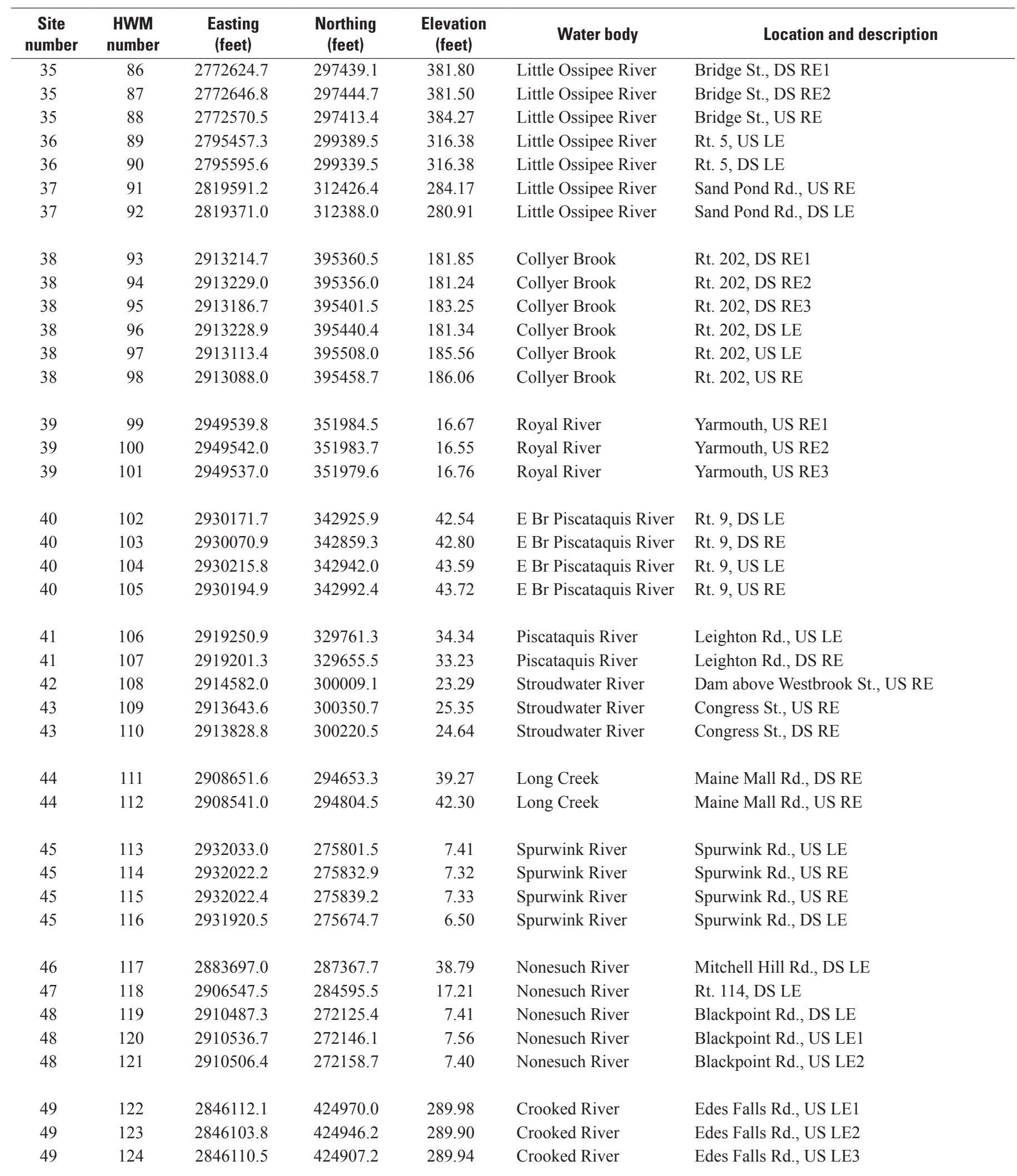


Table 1. Peak water-surface elevations for April 2007 flood in York and Cumberland Counties, Maine.—Continued

[HWM, high-water mark; Northings and Eastings referenced to Maine State Plane West, in feet relative to North American Datum of 1983; elevations, in feet, referenced to North American Vertical Datum of 1988; Rt., route; DS, downstream; LE, left edge of water (when facing downstream); US, upstream; RE, right edge of water; Rd., Road; St., Street; Ln., Lane; RR, railroad; Br., bridge; E Br, East Branch; site number, location shown on figure 2]

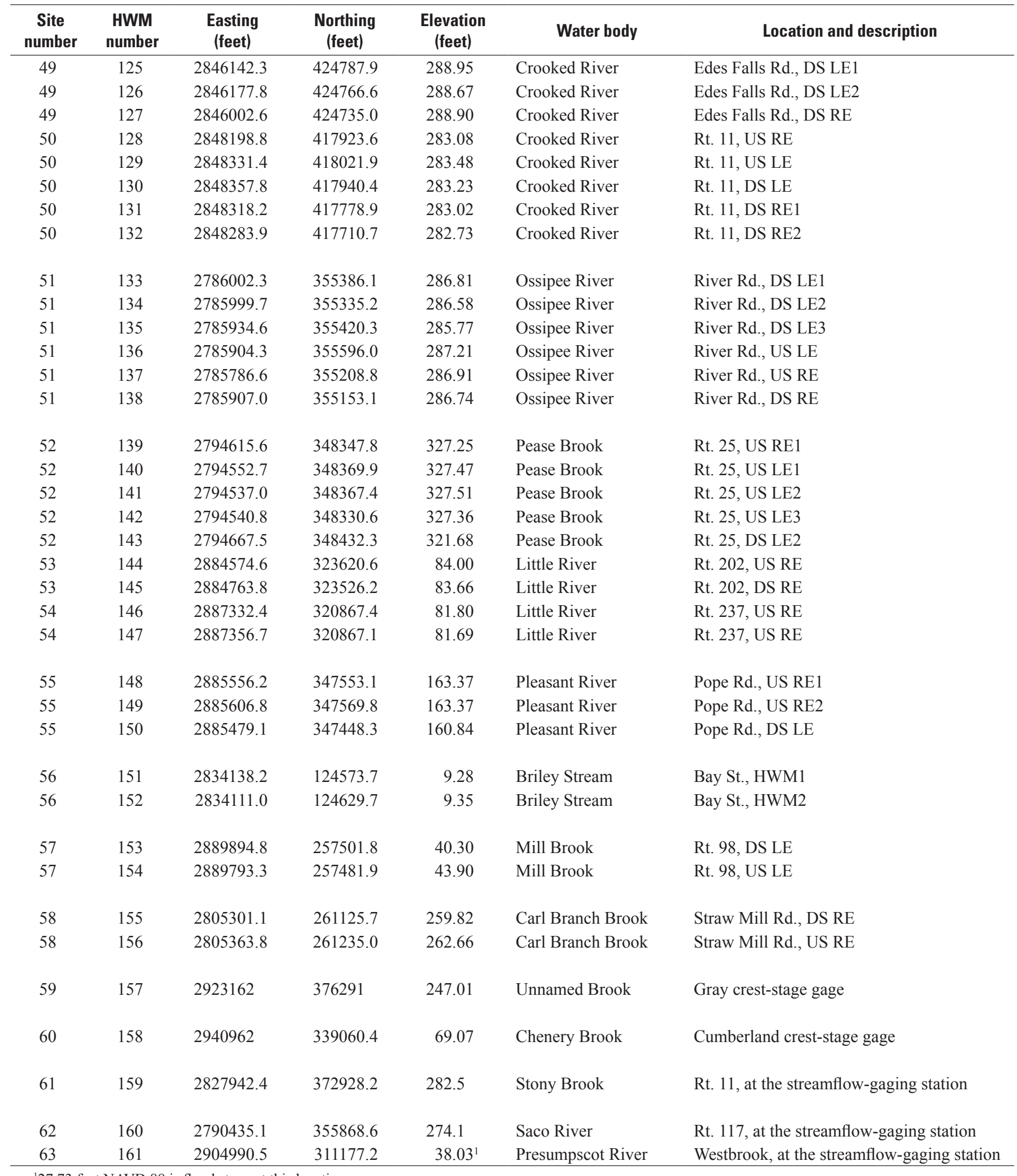

27.73 feet NAVD 88 is flood stage at this location. 
Prepared by the Pembroke Publishing Service Center.

For more information concerning this report, contact:

Director

U.S. Geological Survey

Maine Water Science Center

196 Whitten Road

Augusta, ME 04330

dc_me@usgs.gov

or visit our Web site at: http://me.water.usgs.gov 


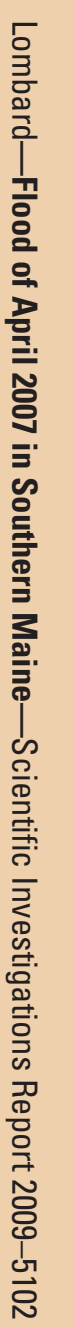

8 Printed on recycled paper 